Arkadiusz Żukiewicz*

\title{
Pedagog społeczny w ujęciu profesor Heleny Radlińskiej
}

\section{Uwagi wprowadzające}

Podejmując się zadania niezwykle odpowiedzialnego z punktu widzenia dyscypliny naukowej, a zarazem silnie związanego z odczuwaną potrzebą powrotu do przeszłości, która przez wiele lat była reglamentowana w przekazie publicznym, słyszałem niejednokrotnie opinie, że obrazowanie koncepcji pedagoga społecznego kreślonej piórem Heleny Radlińskiej jest niemożliwe. Głosy tego typu można oczywiście traktować jako celową demotywację, świadomą próbę kontynuacji milczenia czy też inne formy orientowane na zachowanie status quo polskiej pedagogiki społecznej. Warto jednak rozważać tego rodzaju komunikaty, nadając im znaczenie wyrażanej $\mathrm{w}$ tej formie troski o zamierzoną syntezę. Tak też odnoszę się do uwag czynionych na kanwie zgłoszonego przedsięwzięcia badawczego. Pragnę odczytywać źródłowe teksty jako inspiracje dla współczesnej twórczości naukowej w obrębie pedagogiki społecznej oraz innych, a bliskich tej nauce dziedzin, subdyscyplin i dyscyplin nauki. Nawiązanie do pedagoga społecznego, który jest wiodącym podmiotem rozważań poświęconych działalności środowiskowej: wychowawczej, społecznej, oświatowej, opiekuńczej, kompensacyjnej, pomocowej itp., czyni z zamierzonego opracowania rodzaj swoistego obrazu o głównym aktorze sceny społeczno-pedagogicznej. Dodać warto, że chodzi tu o ujęcie autorskie Heleny Radlińskiej, co ma swe konsekwencje w dalszej konstrukcji wypowiedzi.

W obliczu różnorodnych prób nadawania polskiej pedagogice społecznej znaczeń odległych od zarysowanych przez protoplastkę polskiego rodu pedagogiczno-społecznego, w niniejszym opracowaniu podejmuję próbę oddania głosu samej autorce. Mając świadomość, iż przyjęta forma dalece odbiega od narzucanych w ostatnich latach tzw. standardów wypowiedzi naukowej, podejmuję jednocześnie ryzyko pomówień o intencje, które nie przystoją naukowcom i ich naukowej twórczości. Mam tu

* Uniwersytet Łódzki, Wydział Nauk o Wychowaniu, Katedra Pedagogiki Społecznej. 
na myśli w szczególności zarzut, iż tekst jest przesycony cytatami i odniesieniami do źródeł, zaś w nieznacznym stopniu stanowi wyraz samodzielnej analizy i interpretacji autorskiej. Być może niniejsze wyjaśnienie będzie zrozumiałe dla czyniących zarzuty, stąd poniższa próba dookreślenia i zarazem wyrażenia intencji, które skłoniły mnie do podjęcia się tak trudnego i odpowiedzialnego zadania.

W pierwszej kolejności podkreślam, iż jest to prezentacja pedagoga społecznego w ujęciu Heleny Radlińskiej. Już sam tytuł sygnalizuje to zamierzenie i zdawać się może, iż sprawa jest jednoznaczna. Jednakże w świetle potencjalnych pułapek i możliwych zarzutów kilka informacji uznaję za konieczne. Kreślenie zamierzonego obrazu opieram na założeniu metodologii badań historycznych, w szczególności społeczno-pedagogicznych ${ }^{1}$. Jest on wynikiem analizy tekstów źródłowych, do których dostęp wciąż pozostaje znacznie ograniczony z powodu rozproszenia publikacji Heleny Radlińskiej. Jedyne projekty wydawnicze systematyzujące wybrane fragmenty twórczości tej autorki powiodły się na przełomie lat 50. i 60. XX w. Kontynuacją był wybór pism z roku $1979^{2}$. Wszystkie te zbiory opatrzono nazwiskiem Heleny Radlińskiej. Pamiętać należy jednak, że wydania były pośmiertne i ukazały się w czasie, kiedy oficjalny druk podlegał reglamentacji oraz cenzurze politycznej. Kolejne działania wydawnicze stanowiły niezwykle istotne, ale ograniczone w swych odniesieniach źródłowych próby przybliżenia poglądów i dorobku Heleny Radlińskiej³ . Część z nich ma walor interpretacji. Stanowią swoiste próby współczesnego odczytywania źródeł. W tym kontekście przyjmuję, że nasycenie poniższej wypowiedzi fragmentami cytatów autorskich poświęconych pedagogice społecznej (w szczególności zagadnieniom

${ }^{1}$ Szerzej o badaniu historycznym w pedagogice i pedagogice społecznej zob.: H. Radlińska, W sprawie badań historyczno-pedagogicznych, „Przegląd Historyczny” 1922, z. 2, s. 50-60; H. Radlińska, Program i metoda badania dziejów pracy oświatowej, [w:] taż, Z dziejów pracy spoŁecznej i oświatowej, Ossolineum, Wrocław 1933 (1964), s. 19-36; W. Theiss, Badania historyczno-oświatowe w pedagogice społecznej, „Studia Pedagogiczne” 1982, z. 9, Zeszyty Naukowe Wyższej Szkoły Pedagogicznej w Bydgoszczy, s. 40-54; J. Topolski, Metodologia historii, PWN, Warszawa 1984; S. Palka, Pedagogika teoretycznie i praktycznie zorientowana a badania historii wychowania i myśli pedagogicznej, [w:] T. Jałmużna, I. Michalska, G. Michalski (red.), Konteksty i metody w badaniach historyczno-pedagogicznych, Oficyna Wydawnicza Impuls, Kraków 2004, s. 16-19.

${ }^{2}$ H. Radlińska, Pedagogika społeczna, Ossolineum, Wrocław 1961; taż, Zagadnienia bibliotekarstwa i czytelnictwa, Ossolineum, Wrocław 1961; taż, Z dziejów pracy społecznej i oświatowej, Ossolineum, Wrocław 1964; taż, Oświata i kultura wsi polskiej. Wybór pism, Ludowa Spółdzielnia Wydawnicza, Warszawa 1979.

${ }^{3}$ I. Lepalczyk, B. Wasilewska (red.), Helena Radlińska - portret pedagoga (rozprawy, wspomnienia, materiały), Wydawnictwo Uniwersytetu Łódzkiego, Łódź 1994; I. Lepalczyk, B. Wasilewska (red.), Helena Radlińska. Człowiek $i$ wychowawca, TWWP, Warszawa 1994-1995; W. Theiss, Radlińska, Wiedza Powszechna, Żak, Warszawa 1984, 1997; W. Theiss (red.), Listy o pedagogice społecznej: Helena Radlińska, Aleksander Kamiński, Adam O. Uziembło, Żak, Warszawa 1997; I. Lepalczyk, Helena Radlińska, życie i twórczość, Wydawnictwo Adam Marszałek, Toruń 2001; E. Marynowicz-Hetka, W. Theiss (red.), Profesor Helena Radlińska. W sto dwudziesta piata rocznicę urodzin i pięćdziesiata rocznice śmierci, ŁTN, Łódź 2004 i inne. 
dotyczącym: 1) języka, 2) teoretycznych podstaw rozumienia i wyjaśniania rzeczywistości, 3) metodologii służącej poznawaniu świata z perspektywy społeczno-pedagogicznej, a także 4) metodycznych założeń dla praktyki służby społecznej, oświatowej itp.) prowadzić będzie do tworzenia obrazu pedagoga społecznego, który jest zarówno teoriotwórca, badaczem, wychowawca, nauczycielem, jak i działaczem przetwarzającym rzeczywistość życia gromadnego w imię ideału.

Druga kluczowa kwestia odnosi się do interpretacji oraz podkreślanej współcześnie w postulatach adresowanych do nauki - rekonstrukcji poglądów autorskich Heleny Radlińskiej. Świadomie rezygnuję z dokonywania interpretacji. O ile jest to możliwe, staram się przedstawić wierny obraz poglądów autorki na sprawy związane z konkretnymi zagadnieniami dotyczącymi pedagogiki społecznej, a w konsekwencji pedagoga społecznego. Dokonany wybór mieści się w określonej przeze mnie koncepcji, która stanowi swego rodzaju ramę umiejscowienia poszczególnych kwestii związanych z dyscypliną i jej reprezentantem. Może ona być traktowana jako ingerencja w powstający obraz twórczości autorskiej Heleny Radlińskiej. Jednakże proces i efekt konstruowania wypowiedzi traktuję tu jako nadawanie formy powstającej rekonstrukcji, zaś walor interpretacyjny staram się eliminować z proponowanych poniżej rozważań. Chodzi w szczególności o unikanie sytuacji prowadzących do nadinterpretacji lub błędnego odczytywania autorskich wypowiedzi. Przyjmuje tym samym, że unaoczniony światłem cytowanych fragmentów sposób postrzegania rzeczywistości przez Helenę Radlińską ułatwi czytelnikom bezpośredni kontakt z jej myślą. Musi on być zatem oparty na materiałach źródłowych wyrażających poglądy cytowanej autorki. Istnieje wysokie prawdopodobieństwo, że forma ta będzie również inspiracją dla czytelnika do samodzielnych poszukiwań. Odrzucam przy tym relatywistyczne podejście do analizy tekstów Heleny Radlińskiej bazujące na założeniach kolażu prowadzącego do potwierdzania tez z góry założonych. Interpretacja z zasady jest narażona na niespójność $\mathrm{z}$ intencją przekazu autorskiego. Stąd przyjęta jest tu zasada wierności brzmienia treści wyrażonych przez cytowaną autorkę.

Trzecim i zarazem ostatnim założeniem wstępnym jest dążenie do stworzenia obrazu, który z jednej strony będzie umożliwiał dalsze poszukiwania naukowe współczesnym badaczom spraw społeczno-pedagogicznych. $Z$ drugiej zaś - będzie stanowił inspirację dla praktyków sięgających w refleksji do źródeł swej tożsamości profesjonalnej i dyscyplinarnej. Chodzi w szczególności o nadanie tej wypowiedzi waloru spójnej syntezy będącej punktem wyjścia do dalszych indywidualnych lub zespołowych eksploracji źródłowych nawiązujących do przeszłości przygotowanej z myślą o współczesności i przyszłości. Uzasadnieniem tego zamierzenia jest perspektywa, którą Helena Radlińska wyrażała hasłem: „Kochajmy przeszłość, pracujmy dla przyszłości”4. Jest ono osadzone w realiach

${ }^{4}$ H. Radlińska, Listy o nauczaniu i pracy badawczej, [w:] taż, Z dziejów pracy społecznej i oświatowej, Ossolineum, Wrocław 1953-1954 (1964), s. 331. 
społecznego romantyzmu, który wyznaczał autorce kierunki aktywności w życiu prywatnym i publicznym od czasów szkolnych.

Każde z powyżej wyrażonych założeń wstępnych odgrywa rolę wyjaśnienia intencji i perspektywy, z której prowadzone są dalsze rozważania. Na marginesie pozostają jednak liczne możliwe reakcje adresatów tego opracowania, które $\mathrm{z}$ założenia będą inspirowały $\mathrm{w}$ dalszych historycznych poszukiwaniach prowadzonych na gruncie dziedziny społeczno-pedagogicznej, którą Helena Radlińska określała mianem historii działalności społecznej i oświatowej. Ten nurt zasługuje bowiem w moim odczuciu na dalszy rozwój, gdyż dorobek przeszłości ułatwia potomnym korzystanie z otwartych już drzwi. Unika się przy tym marnotrawienia energii i czasu na działania, które podjęli poprzednicy, szczególnie w sytuacjach, gdy ich osiągnięcia w danej dziedzinie były skuteczne i pożyteczne dla współtworzonego dobra wspólnego. Kontynuacja nie musi bowiem oznaczać powielania i naśladownictwa. Może być wyrazem rozsądku i racjonalnego spożytkowania dóbr wytworzonych przez minione pokolenia działaczy, badaczy czy teoriotwórców. Zwolennicy rewolucji, zerwań czy innych form sprzeciwu wobec „minionego" starają się przekonać, że siłą napędową rozwoju jest kontestacja odrębności i odrzucenie przeszłości ${ }^{5}$. Koncentracja na teraźniejszości i przyszłości ma być drogą bez uwikłania $\mathrm{w}$ dylematy $\mathrm{z}$ przeszłości. Jednakże rewolucja niesie ze sobą liczne konsekwencje w postaci strat, ofiar i towarzyszących temu napięć skutkujących kolejnymi dylematami. Niejednokrotnie stanowi źródło satysfakcji jednych i cierpienia innych. Stąd przyjmuję, że zasadne jest poszanowanie przeszłości i jej znajomość. Dodać można, że wymaga to wysiłku oraz uwagi dziedziców, ale niesie ze sobą liczne pożytki. Perspektywa taka pozwala bowiem sięgać po instrumenty rewolucyjne tam, gdzie stanowić mogą bezpieczne oprzyrządowanie służące rozwojowi i zmianie rzeczywistości życia ludzkiego. Być może konwergencja podejścia ewolucyjnego i rewolucyjnego jest możliwa. Jeśli tak, warto dążyć do urzeczywistnienia owego ideału łączenia dodatnich elementów różnorodnych podejść służących podnoszeniu poziomów jakości i kultury życia codziennego każdego człowieka naszego globu.

\section{Operacjonalizacja języka pedagoga społecznego}

Jednym z narzędzi analizy czynię tu język, który wyznacza przedstawicielom określonych dyscyplin i profesji sposób postrzegania oraz wyrażania stanowisk na temat rzeczywistości, stanów, zdarzeń i procesów dokonujących się w przestrzeniach ich aktywności. Operacjonalizowanie formy wyrazu myśli, przeżyć,

${ }^{5}$ Przykładem może być koncepcja Thomasa S. Kuhna, który prezentuje rewolucyjną drogę naukowego rozwoju. Zob. szerzej: T. S. Kuhn, Struktura rewolucji naukowych, Wydawnictwo Aletheia, Warszawa 2009. 
odczuć czy doświadczeń, które towarzyszą służbie pedagoga społecznego w polu teorii i praktyki stanowi jedną z kluczowych czynności podejmowanych podczas współtworzenia dobra służącego osobom, rodzinom, grupom ludzkim czy też całym społecznościom. Wypracowany język ułatwia nie tylko komunikację wewnątrz środowiska określonej profesji czy dyscypliny. Staje się również dla pedagoga społecznego swoistym wyznacznikiem sposobu rozumienia i prezentacji własnego punktu widzenia. Jest to istotne w kontekście postrzegania określonych zagadnień będących równolegle przedmiotem zainteresowania i oddziaływania profesjonalistów wywodzących się z innych (mniej lub bardziej pokrewnych) profesji lub dyscyplin.

Poniższa prezentacja opiera się na celowym doborze kluczowych kategorii społeczno-pedagogicznych, które do języka pedagoga społecznego wprowadziła Helena Radlińska. Nie obejmuje ona kompletnego katalogu leksykalnego. Nie jest też opatrzona komentarzem. Sięgając do tekstów źródłowych, staram się zachęcić do indywidualnej lektury pogłębiającej znajomość prezentowanych kwestii w oparciu o autorskie opracowania H. Radlińskiej.

Podstawową kwestią w tym fragmencie prezentacji jest rozumienie pedagogiki społecznej zarówno jako nauki, jak i praktyki służby. Już w okresie międzywojennym Helena Radlińska charakteryzowała tworzącą się dyscyplinę w następujący sposób:

Pedagogika społeczna kształtuje się jako dział nauki odrębny od socjologji wychowania. Zbliża się do polityki społecznej, korzysta z jej koncepcji i poszukiwań. [...] Pedagogikę społeczną interesuje przedewszystkiem wzajemne oddziaływanie wpływów środowiska i przekształcających środowisko sił jednostek. W ich związkach odnajduje cele, stawiane świadomej czynności wychowawczej, w ich świetle charakteryzuje używane środki działania ${ }^{6}$.

U schyłku swej twórczości akademickiej cytowana autorka wyjaśniała, że:

Pedagogika społeczna jest nauką praktyczną, rozwijającą się na skrzyżowaniach nauk o człowieku, biologicznych i społecznych z etyką i kulturoznawstwem (teorią i historią kultury) dzięki własnemu punktowi widzenia. Można go najkrócej określić jako zainteresowanie wzajemnym stosunkiem jednostki i środowiska, wpływem warunków bytu i kręgu kultury na człowieka w różnych fazach jego życia, wpływem ludzi na zapewnianie bytu wartościom przez ich przyjęcie i krzewienie oraz przetwarzanie środowisk „siłami człowieka w imię ideału”.

Dziedziny badań i przemyśleń pedagogiki społecznej rozszerzają się w związku z występowaniem w życiu nowych zagadnień. Wpływają na nie osiagnięcia zarówno myśli teoretycznej, jak i doświadczeń praktycznych.

Znajomość rozwoju człowieka pedagogika społeczna uzyskuje przy pomocy nauk biologicznych i lekarskich, psychologii (rozwojowej, wychowawczej i społecznej), nauk pedagogicznych (zwłaszcza pedagogiki leczniczej). Pedagogika społeczna, spożytkowując wyniki tych nauk,

${ }^{6}$ H. Radlińska, Stosunek wychowawcy do środowiska społecznego. Szkice z pedagogiki spotecznej, Nasza Księgarnia, ZNP, Warszawa 1935, s. 15. W cytatach została zachowana pisownia oryginalna. 
urzeczywistnia syntezę o człowieku. Przekracza postulaty wysunięte dla takiej syntezy (m.in. przez A. Carrela i J. Pietera), wiążąc sprawy życia indywidualnego i zbiorowego, poszukując sposobów dostarczania podniet rozwoju i usuwania jego przeszkód.

$\mathrm{Z}$ rozległych spraw kultury pedagogika społeczna rozpatruje przede wszystkim warunki oraz sposoby uczestnictwa w jej dorobku i wyzwalaniu nowej twórczości. W zakresie życia społecznego spożytkowuje dane socjologii i polityki społecznej dla własnych poszukiwań. Dotyczą one przebiegów przemian społecznych i roli w nich działalności celowej.

W ocenie wpływu poszczególnych czynników pedagogika społeczna sięga po pomoc historii (zwłaszcza historii kultury i wychowania, historii społecznej i gospodarczej, historii ruchów społecznych $)^{7}$.

Kontynuując charakterystykę dyscypliny, którą osobiście zaproponowała i rozwijała w polskiej nauce Helena Radlińska, wskazała ona zasadnicze działy pedagogiki społecznej, które stanowią klasyczny jej fundament. Autorka stwierdzała w skrypcie powielonym w roku 1951 przez studentów Koła Naukowego Pedagogów Społecznych Uniwersytetu Łódzkiego Egzaminie z pedagogiki spotecznej, że:

W obrębie pedagogiki społecznej wystąpiły wyraźnie trzy działy stanowiące ściślejszą specjalizację pracowników naukowych, opartą na znajomości podstawowych zagadnień wspólnych. Są nimi: teoria pracy społecznej, teoria oświaty dorosłych oraz historia pracy społecznej i oświatowej. Dzięki ich osiągnięciom pod wpływem potrzeb życia kształtują się nowe działy. [...]

Nazwa pedagogiki społecznej wyraża jej rolę łącznika pomiędzy zespołem nauk o wychowaniu i nauk o kulturze i społeczeństwie ${ }^{8}$.

Zagadnieniem, które w naturalny sposób wpisuje się jako konstytutywne dla pedagogiki społecznej, jest wychowanie. Stanowi ono swoistą oś, wokół której budowane są określone koncepcje, teorie i modele metodyczne generowane na gruncie pedagogiki społecznej. Podejmując zagadnienie wychowania w okresie międzywojennym, Helena Radlińska odnosiła się do stanowisk inspirowanych twórczością Paula Bergemanna. Wyjaśniała przy tym, że:

Wychowanie jest funkcją społeczną. Praw dla niego szukać należy w życiu samem - rozumuje Bergemann. Naczelnem zjawiskiem w życiu społecznem jest rozwój kultury, powołaniem człowieka tworzenie i doskonalenie kultury swego narodu, rolą narodów - wnoszenie zdobyczy kulturalnych w życie ludzkości. Każda praca, każde usiłowanie, by jakiś ideał kulturalny w czyn wcielić, sprzyja rozwojowi ludzkości. [...] Pedagogika społeczna rozpatruje wychowanie jednostki w związku z życiem grupy społecznej, której jest dzieckiem, w związku - z życiem narodu 9 .

Podnoszony w przywołanym fragmencie źródeł przymiotnikowy wymiar wychowania odwołuje się do czasów rekonstruowania systemu wychowawczego

\footnotetext{
${ }^{7}$ H. Radlińska, Pedagogika społeczna, s. 361-362.

${ }^{8}$ Tamże, s. 362.

${ }^{9}$ H. Radlińska, Stosunek wychowawcy do środowiska społecznego, s. 10-11.
} 
opartego na idei wskrzeszania narodu po przeszło stuletnim okresie rozbiorów Rzeczypospolitej Polskiej. Zwracała na to szczególną uwagę sama autorka, pisząc wprost:

Niewola szkoły w zaborze rosyjskim nie zabiła wychowania narodowego. Szło ono krętymi ścieżynami, nad przepaściami najgroźniejszych niebezpieczeństw chwytała się wątpliwych gałązek i nadawało im moc hartowaną. Uproszczone elementarze, literatura popularyzacyjna, samokształcenie wspomagane umiejętnie, kółka i kółeczka oświatowe wpływy wynaradawiające i nietylko przechowywały niejedno ze wspaniałej póścizny, lecz stworzyły nowe doniosłe wartości społeczne i kulturalne. [...]

Wychowanie narodowe nie zamarło w niewoli, tak jak nie zamarło życie narodu. W najgorszych warunkach przygotowywały się pokolenia do podjęcia swych zadań. Wbrew wszystkim przeszkodom rozszerzyło się łożysko życia narodu. Język, wygnany ze szkoły, nie stracił siły i czaru, lecz nowym zajaśniał przepychem. Książka polska trafiła pod strzechy. Tradycję walki o wolność przejął lud. Po za obcym systematem szkolnictwa wychowanie narodowe stworzyło wzorowe własne instytucje ${ }^{10}$.

Podkreślany przez autorkę język ojczysty odegrał znaczącą rolę w procesie zachowania narodowej tożsamości. Mimo zewnętrznej (obcej) aktywności narzucającej rygory prawne obwarowane licznymi sankcjami karnymi (włącznie $\mathrm{z}$ zesłaniem $\mathrm{w}$ niewolę, utratą mienia, a nawet życia), za sprawą m.in. wychowania narodowego udało się Polakom zachować w pamięci wielu pokoleń miłość do utraconej ojczyzny. Z owej pamięci i szacunku rodziło się pragnienie odzyskania wolności oraz odbudowy państwa polskiego. Warto współcześnie stawiać pytania o kulturę języka polskiego, do którego wciąż włącza się liczne elementy zaczerpnięte z obcych kultur. Przykładem może być dawny „,proletariusz”, a współczesny „,interesariusz” czy „prekariusz”. Nie miejsce tu, by rozstrzygać słuszność przejmowania, a niekiedy wręcz promowania słownictwa budzącego dysonans w zderzeniu $\mathrm{z}$ kultura języka polskiego, ale warto $\mathrm{z}$ refleksją poddawać tego typu procesy analizie prowadzącej do wnioskowania służącego społecznemu konstruowaniu rzeczywistości życia codziennego. Poszanowanie odrębności oraz tolerancja dla inności nie zobowiązuje do bezrefleksyjnego przyjmowania wzorów obcych kulturowo, w tym językowo. Zdaje się, że budowanie jedności na wielorodności i poszanowaniu odrębności jest drogą, która może prowadzić do wzajemnego zrozumienia i współdziałania w skali mikro, mezo i makro.

W odniesieniu do istoty wychowania stanowiącego centralną pozycję w katalogu twórczości i aktywności pedagoga społecznego Helena Radlińska stwierdzała, że „wychowawcę pociaga przede wszystkiem sprawa odnajdywania sił działalnych: tych, które są znane i utajonych" ${ }^{11}$. Dalej pisała:

\footnotetext{
${ }^{10}$ Tamże, s. 11-12.

11 Tamże, s. 18.
} 
Wychowanie - stanowi dziedzinę wyraźnie nastawioną na cele jutrzejsze. Jeden z najwybitniejszych Polaków określił trafnie, że polityk buduje z materjałów, które są do rozporządzania, zużywając nawet najlichsze, ale ktoś musi robić cegły. Ta rola przypada nietylko wychowaniu, owszem - jest ono raczej działaniem pomocniczem, które uruchamia istniejące wartości, uprzystępnia je, czyni z nich narzędzia dalszego trudu. Wychowanie jest tylko częścią tworzenia kultury. Posiada jednak własne pole twórczości.

Istotę jej stanowi wydobywanie wartości jednostek i grup ludzkich w celu wprowadzenia w życie odwiecznego dążenia do doskonaleń.

W imię ideału, siłami człowieka wychowanie przetwarza dzień dzisiejszy - ideału owego lepszego jutra, które żyje również w teraźniejszości, lecz niedość silnie, jeszcze niedość rozrosłe. Buduje w jego imię instytucje przyszłości. Sięgając do bogatych tradycyj polskich, można się wyrazić: - tworzy w każdym dniu bieżącym „nowe osady” narodów ${ }^{12}$.

W nawiązaniu do społeczno-pedagogicznej perspektywy postrzegania procesów oddziaływania wychowawczego, Helena Radlińska wyjaśniała, że:

Pojęcie wychowania w pedagogice społecznej obejmuje wspomaganie autonomicznych przebiegów rozwoju i wrastania, nasycanie gleby wrastania wartościami dorobku dotychczasowego oraz wprowadzanie w istniejący dorobek myśli i pracy, uczenie umiejętności wyboru, stawianie celów życia i pracy, budowania dróg do nich wiodących, usprawnianie w korzystaniu z narzędzi i sposobów dalszej twórczości.

Wychowanie tak pojęte opiera zamierzoną działalność wychowawczą na spożytkowaniu wszystkich dziedzin twórczości. Obejmuje cały przebieg życia ludzkiego, wszelką działalność, w której człowiek, stykając się z instytucjami i z ludźmi, poddając się ich wpływom, wnosi własne wartości. Przedmiotem badań są nie tylko sprawy jednostek, lecz i grup ludzkich, nie tylko oddziaływanie wychowawcy, lecz również samowychowanie i samokształcenie indywidualne i zespołowe ${ }^{13}$.

Operacjonalizując język pedagoga społecznego w koncepcji kreślonej przez Helenę Radlińską, konieczne jest zwrócenie uwagi na kategorie towarzyszące wychowaniu. Należą do nich pojęcia związane z kluczowymi obszarami aktywności teoriotwórczej i praktycznej pedagoga społecznego. Wiodącym obszarem jest tu wprowadzanie w kulturę i przygotowanie do przejmowania oraz tworzenia wartości. Na tym tle jawią się trzy zasadnicze kategorie, które w polskiej pedagogice społecznej i zarazem w języku pedagoga społecznego odgrywają znaczącą rolę. Mowa o wzroście, wrastaniu i wprowadzaniu. Sama autorka definiuje je w następujący sposób:

W z r o s t (w tym znaczeniu rozwój osobniczy) odbywa się z zadatków, które człowiek otrzymuje poza swą wolą, wedle praw, których zmienić niepodobna. Najbardziej przemyślane zabiegi nie mogą ukształtować genów przenoszących dziedzictwo nieznanych przodków, potrafią co najwyżej zapobiec niektórym przewidzialnym niebezpieczeństwom grożącym rodzicielce i dziecku.

Nikt nie może zastąpić rozwijającej się jednostki w jej przeżyciach. Niepodobna przyśpieszyć wzrostu wbrew naturze: nauczyć chodzić lub mówić, zanim nadejdzie odpowiednia chwila. Nie przyjmą się zaszczepiane przedwcześnie pojęcia nie znajdujące oparcia o przeżyte doświadczenie lub dążenia osobiste.

\footnotetext{
${ }^{12}$ Tamże, s. 19.

${ }^{13}$ H. Radlińska, Pedagogika spoteczna, s. 362-363.
} 
Wzrost fizyczny i duchowy splatają się ze sobą nierozerwalnie. W życiu duchowym wzrost nie ma kresu (choć w dziedzinie czysto intelektualnej zna zgrzybiałość). Pierwiastki wlane człowiekowi wraz z życiem, wieczne, potęgują charakter autonomiczny wzrostu. Dzięki nim niepodobna zniszczyć życia ludzkiego, gdyż przezwyciężają one śmierć pojęciem zwycięstwa za grobem.

Wrastanie wiążące jednostkę ze środowiskiem jest podobnie jak wzrost przebiegiem samorzutnym. Odbywa się w zależności od przebiegu wzrostu. W dzieciństwie najbliższe otoczenie wydaje się jedynie naturalnym: dziecko chłonie wpływy ludzi, przyrody, rzeczy. Przyzwyczajanie się do jakiegoś porządku spraw wiąże je z grupą. Mowa, którą przejmuje nieświadomie, uspołecznia świtającą myśl. W okresie przekory i później w czasie narodzin świadomości młodzi przeciwstawiają się uznawanym dotychczas autorytetom i stosunkom, pożądają odmiany. Postawa wobec środowiska z uległej staje się obronną, przechodzi w czynną. Następuje - w sprzyjających warunkach - świadome wrastanie w środowisko szersze. Dzięki odnajdywaniu spuścizny, przenoszeniu wzorów i przejmowaniu dążeń krzewi się tradycje i rozrastają ruchy społeczne. Twórczość życiowa jednostek dojrzałych zapewnia byt i promieniowanie przejętym wartościom, wzmacnia je własnymi siłami. Rozwaga starości przypomina to, co w nich najtrwalsze.

Wrastanie wymaga czasu na zakorzenianie i rozkrzewianie właściwe dla danego okresu wzrostu. Jest głębokie i mocne tylko w glebie wartości trwałych.

W prowadzanie odbywa się przez pomoc udzielaną generacji młodszej lub ludziom poszukującym narzędzi i metod rozwiązywania zadań, które życie stawia przed nami. Wskazuje sposób postępowania przykładem, wtajemnicza w obyczaje, wierzenia i w wiedzę, uczy sprawności, umiejscawia w zawodzie i w społeczeństwie.

Wprowadzaniem zajmują się rodzice i wychowawcy, rówieśni bardziej doświadczeni i niewiele starsi. W stosunku do zawodowej pracy fizycznej nazwano je „holownictwem”, gdyż przodownicy pociagają za sobą niewtajemniczonych jeszcze lub niewprawnych. Uczestnictwo dotyczy nie samej tylko szkoły. Jest terminowaniem w zawodzie, wdrażaniem się do wszelkiej pracy wymagającej wyszkolenia.

Wprowadzanie nie jest ograniczone wiekiem. Zależnie od dziedzin życia i pracy zwraca się ku ludziom młodym lub dojrzałym jako poradnictwa fachowe, prawne, wychowawcze, jako przeszkolenie mistrzowskie, czy nawet ,generalskie”.

Skuteczność wprowadzania zależy od liczenia się z przebiegami samorzutnymi wzrostu i wrastania, tj. z istnieniem przeżyć, które pozwalają na zrozumienie, na naśladowanie czy spożytkowanie jego świadczeń ${ }^{14}$.

W toku dalszego wywodu autorka podkreślała, że każda z czynności wymaga planowej, wszechstronnej i systematycznej pomocy. W szczególności konieczne jest bowiem tworzenie warunków, w których przebieg wzrostu, wrastania i wprowadzania będzie wolny od deficytów i zahamowań. Zapewnią to działania o charakterze kompensacyjnym, ratowniczym, opiekuńczym i pomocowym. To zaś prowadzi do kolejnych pojęć, które dla pedagoga społecznego stanowią zoperacjonalizowane narzędzia postrzegania, rozumienia i wyrażania rzeczywistości.

Przedstawiając zagadnienia fundamentalne dla pedagogiki społecznej, Helena Radlińska wskazała na kompensację. Wyraziła to wprost pisząc, że „Głównem zagadnieniem pedagogiki społecznej jest zagadnienie kompensacji, świadomie uzupełniającej procesy selekcji społecznej i biologicznej" "15. Rozwijając tę kwestię, autorka dookreśliła, iż:

\footnotetext{
${ }^{14}$ H. Radlińska, Zasięg wychowania, ,Ruch Pedagogiczny” 1946, nr 1, s. 38-39.

${ }^{15}$ H. Radlińska, Stosunek wychowawcy do środowiska społecznego, s. 16-17.
} 
W pedagogice społecznej kompensacja oznacza celowe wyrównywanie braków, zupełnianie lub zastępowanie niepomyślnych składników sytuacji osobistej czy grupowej, stwarzanie warunków życia uznawanych za normalne. W subiektywne środowiska upośledzone wprowadza wartość środowiska obiektywnego. Wzmacnia słabych pomocą silnych, przy braku lub zerwaniu istniejących więzi zadzierzguje nowe. Kompensacja społeczna, działając z zewnątrz, spożytkowuje i wspomaga zjawiska samorzutnej kompensacji psychologicznej, poddając im treść społeczną i zapobiegając nadkompensacji (przerostowi cech wyrównywających).

Zagadnienia kompensacji były dotychczas najpełniej omawiane w związku z różnymi formami pomocy społecznej. Poruszano je także w dziedzinie spożytkowywania wczasów i w pedagogice leczniczej. W badaniach wystapiło znaczenie kompensacji, jako jednego z najważniejszych czynników planowania przekształceń środowisk ${ }^{16}$.

Obok kompensacji występują kolejne kategorie, którym Helena Radlińska nadawała specyficzne znaczenie. Wpisując te kategorie do pedagogiki społecznej, wskazała tym samym sposób ich rozumienia dla osób identyfikujących się z dyscypliną i zarazem profesją. Stąd można jednoznacznie przyjąć, że dla pedagoga społecznego wpisującego się w dyscyplinarną koncepcję Heleny Radlińskiej pojęcie ratownictwa, pomocy i opieki są jednoznaczne i oznaczają odpowiednio:

R a t o w n i c tw o (zwane niekiedy pomocą doraźną) zjawia się w chwilach niebezpieczeństw osobistych i masowych: wypadków, katastrof. Narzuca je konieczność, ale oparcie stanowi poczucie moralne, nawet wówczas, gdy formy ratownictwa zostają utrwalone przez obyczaj i prawo.

Pomoc, przejawiająca się w różnych dziedzinach i formach (np. dostarczanie środków materialnych, robocizny, porady, podtrzymania duchowego), ma na celu wzmacnianie sił w chwilach trudnych, usuwanie przeszkód zbyt wielkich do pokonania przez jednostkę czy drobną grupę. Jedną z cech pomocy była wzajemność. Wyrażała się ona najpełniej we współdziałaniu rolniczym i w urządzeniach przezorności (ubezpieczenia wzajemne, kasy pogrzebowe itp.). W miarę rozluźniania się więzi rodowych, sąsiedzkich, parafialnych, gminnych pomoc jest włączana do zadań państwa organizującego ubezpieczenia społeczne, wspomagającego dotkniętych klęskami, potrzebujących porady prawnej, zawodowej. Wiele dziedzin pomocy nie może się jednak pomieścić w ramach instytucji publicznych i szuka innych rozwiązań - w działaniach ochotniczych.

O p i e k a różni się od pomocy tym, że sprawująca ją osoba lub instytucja opiekuńcza bierze na siebie odpowiedzialność za ,podopiecznego". Przewiduje to prawo cywilne w stosunku do niepełnoletniego, do chorego umysłowo, ubezwłasnowolnionego. Opieka społeczna jest stosowana wobec członków społeczeństwa „niezdolnych do samodzielnej egzystencji materialnej”. Na ten rodzaj opieki wpłynęły tradycje bardzo od siebie różne: dobroczynności (płynące z motywów religijnych bądź z humanitaryzmu filozoficznego), którą kierowało poczucie obowiązku wobec bliźniego oraz porządku publicznego, który wymaga usuwania tego, co zatruwa życie ogółu. Tradycje policyjne pozostawiły ślad wyraźny w stosunku do ,podopiecznych”, ograniczonych w swych prawach obywatelskich.

Wyraz „opieka” jest nadużywany, zwłaszcza w języku polskim, który zapomniał o szerszym znaczeniu wyrazu ,pomyślność” i niejedno urządzenie pomyślności społecznej mianuje opiekuńczym. Dzieje się tak w znacznym stopniu dlatego, że urządzenia zapobiegające nędzy i podnoszące poziom życia ogółu powstawały na podłożu działalności opiekuńczej ${ }^{17}$.

\footnotetext{
${ }^{16}$ Radlińska H., Egzamin z pedagogiki społecznej, [w:] taż, Pedagogika społeczna, s. 370-371.

${ }^{17}$ Tamże, s. 378-379.
} 
Zachowując w pamięci deklarację wstępną o unikaniu interpretacji w toku prowadzonego wywodu, nie podejmuję takiej próby w kontekście stosowanego przez Helenę Radlińską określenia podopieczny. Autorka stosuje przy tym cudzysłów, na co warto zwrócić uwagę. W kontekście prowadzonych współcześnie rozważań o uogólnieniach i kategoryzacjach osób korzystających z różnego typu form wsparcia oferowanych przez system pomocy i integracji społecznej, może to być inspiracja i zarazem wskazówka dla poszukujących universum. Ludzie i grupy społeczne, które sięgają po pomoc, opiekę i inne formy wspomagające ich w pokonywaniu trudności życia codziennego, są powszechnie określane mianem klientów. Sprawa ta zasługuje na głębszą uwagę, szczególnie w poszukiwaniu i kształtowaniu tożsamości polskich służb społecznych po zmianie systemowej zapoczątkowanej ustawą o pomocy społecznej z $1990 \mathrm{r}$.

Kategoriami, które dla pedagoga społecznego widzianego oczami Heleny Radlińskiej stanowią fundament ich tożsamości zarówno dyscyplinarnej, jak i profesjonalnej, są również takie, jak w szczególności: środowisko, siły (ich poszukiwanie i wspomaganie oraz aktywizacja), pokolenie historyczne (generacje), wiek społeczny (wiek inteligencji, wiek fizjologiczny), struktura życiowa zawodu, normy, wzorce i mierniki, a także diagnoza i profilaktyka społeczna. Każda z wymienionych kategorii współtworzy język pedagoga społecznego, który w codziennej służbie podejmowanej w różnorodnych polach życia gromadnego posługuje się nim w komunikacji z partnerami współdziałalności społecznej. Wprowadzając poszczególne kategorie do słownika pedagogiki społecznej, nadawała im Helena Radlińska określone znaczenie, typowe dla kreślonej własnym piórem dyscypliny. W odniesieniu do środowiska zauważała ona, że:

Szereg badaczy zagadnień społecznych środowiskiem nazywa zespół warunków, wśród których bytuje jednostka i czynników, kształtujących jej osobowość, oddziaływujących stale lub przez dłuższy czas. W tem ujęciu „środowisko” może być przeciwstawione „otoczeniu”. Otoczenie zmieniamy ciągle, przechodząc z domu przez ulicę do szkoły, warsztatu, sklepu, do znajomych, kościoła, do teatru. Wszędzie idzie z nami wpływ środowiska, który czasem rozstrzyga o wyborze otoczenia, zwykle oddziaływuje na zachowanie się w nowym otoczeniu, na stosunek do chwilowego otoczenia.

Wśród składników środowiska można rozróżnić: przyrodę, warunki bytu, wytworzone przez pracę ludzką i stosunki pomiędzy ludźmi, z nich wynikające: osoby działające i reagujące na oddziaływanie różnorodnych czynników i wytwory ducha ludzkiego: wierzenia, naukę, literaturę, sztukę, przeżycia, nastawienia psychiczne.

Do składników środowiska należy przeszłość na równi z teraźniejszością.

Podobieństwa i różnice środowisk sprawiają, że te same lub odmienne cechy występują u gromad ludzkich, przyczem rozmaita bywa siła oddziaływania różnych czynników ${ }^{18}$.

W syntezie opracowanej pod koniec życia i równocześnie w czasie administracyjnego (warunkowanego względami politycznymi) zakazu pełnienia funkcji nauczyciela akademickiego (w tym kierownika Zakładu Pedagogiki

${ }^{18}$ H. Radlińska, Stosunek wychowawcy do środowiska społecznego, s. 29-30. 


\section{Społecznej, który został rozwiązany) na Uniwersytecie Łódzkim ${ }^{19}$, cytowana autorka podkreślała, że:}

Środowisko w przeciwieństwie do otoczenia zostało określone jako „zespół warunków, wśród których bytuje jednostka, i czynników przekształcających jej osobowość, oddziałujących stale lub przez czas dłuższy".

Pedagogika społeczna zajmuje się stosunkiem jednostek i grup do środowisk życia (przyrodniczego, kulturowego i osobowego) oraz ich rolę jako składników środowisk i czynników przemian.

Rozróżnione zostały w odmiennych przekrojach środowiska bezpośrednie i szersze, subiektywne i obiektywne, materialne i niewidzialne. W stosunku człowieka do środowiska pedagogika społeczna bada przyczyny i cechy postaw: biernej, obronnej i twórczej.

W charakterystyce środowiska niewidzialnego interesuje się przede wszystkim jego udziałem w motywach postępowania, rolą twórczą w przebudowie społecznej.

Twórczość, do której wszyscy są zdolni, jest w pedagogice społecznej rozumiana jako przejmowanie wybranych dóbr, nadawanie im życia przez odtwarzanie ich w sobie, pomnażanie ich dzięki spożytkowywaniu jako podstawy własnych dążeń i czynów.

Twórczość jednostek wybitnych w zakresie nauki, sztuki, techniki znajduje oddźwięk i wywiera wpływ tym większy, im wyższy i równiejszy jest poziom powszechnej twórczości życia.

W dokonujących się przemianach środowisk pedagogika społeczna zwraca uwagę na istotę i znaczenie przodownictwa (osób i urządzeń). Opracowując zagadnienia więzi jednostki ze środowiskiem, bada przyczyny wysferzenia się i życia na „marginesie społecznym” sposoby nawiązywania nowych więzi i rozszerzania kręgu środowiska ${ }^{20}$.

\section{O kolejnej z wymienionych kategorii - pokoleniu historycznym - pisała Helena Radlińska, że:}

Wszystkie roczniki wieku współżyjące w danej chwili w obliczu tych samych wydarzeń i tych samych zadań stanowią pokolenie historyczne. Poszczególne generacje tego pokolenia różnią się przeżyciami, zasobem doświadczeń i możliwościami działania.

Biologiczne podstawy życia społecznego, tj. udział w społeczeństwie poszczególnych generacji oraz stan ich sił i zdrowia, odmienne w rożnych okresach dziejowych i w rożnych krajach, mają wpływ na planowanie i wykonywanie prac społecznych i kulturalnych.

Na podstawie licznych badań pedagogika społeczna stwierdziła, że wartości poszczególnych okresów życia są w znacznym stopniu wartościami utajonymi. Ujawnienie ich w pełni i spożytkowanie zależy od warunków społecznych. Przekształcanie tych warunków wymaga świadomości roli generacji dojrzewających i dojrzałych.

Zrozumienie współżycia generacji pokolenia historycznego wymaga rozpoznania ich cech charakterystycznych, ich potrzeb i wykonywanych zadań.

Pedagogika społeczna kładzie nacisk na spożytkowanie swoistych możliwości wszystkich generacji, stąd zainteresowanie organizacją środowiska rozwoju i wrastania, wprowadzaniem w umiejętności odnajdywania i wybierania wartości przez młodocianych, dopomaganiem w twórczości młodzieży, zapewnianiem oparcia dorosłym w ich odpowiedniej pracy, spożytkowywaniem doświadczeń starych.

${ }^{19}$ Szerzej o łódzkim okresie życia i aktywności zawodowej Heleny Radlińskiej zob: H. Radlińska, Listy o nauczaniu i pracy badawczej, s. 462-473; W. Theiss (red.), Listy o pedagogice społecznej, s. 30-183; I. Lepalczyk, Helena Radlińska: życie i twórczość, Wydawnictwo Adam Marszałek, Torun 2001, s. 134-183.

${ }^{20}$ H. Radlińska, Egzamin z pedagogiki społecznej, s. 366. 
Pojęcie pokolenia historycznego i ocena roli jego generacji zostały spożytkowane w badaniach nad rodziną, nad rolą instytucji przynoszących jej pomoc społeczną, nad dziejami prądów i ruchów społecznych $^{21}$.

Uzupełnieniem powyższego są uwagi, które autorka przedstawiła już w 1935 r. przy okazji prezentacji wyników badań prowadzonych w Warszawie w środowiskach rodzin, których dzieci przekraczały próg szkolny. Pisała wówczas o współżyciu w pokoleniu historycznym, podkreślając, iż:

Przyszłość wykuwają wychowawcy wraz z wychowankami.

Rozważanie tej sprawy wymaga uprzytomnienia faktu społecznego, o którym teoretycy wychowania nieraz zapominają. Faktu - współżycia ludzi, należących do trzech generacyj wedle wieku, którzy stanowią razem jedno pokolenie historyczne. [...]

Dziadkowie, ojcowie, wnuki pracują w jakichś chwilach równocześnie, są nietylko świadkami, lecz i współuczestnikami tych samych częściowo wydarzeń. Siły społeczne różnych krajów i czasów zależą wśród innych czynników - od różnicy składu ludności wedle grup wieku. Przewaga sił duchowych i fizycznych jednej z grup pokolenia historycznego nadaje barwę życiu kraju czy epoki. Przemiany duchowe następują jednak we wszystkich grupach, żyjących współcześnie. O ich wspólności stanowią wydarzenia bieżące i wpływy środowiska, o odmienności - różnice miary sił, doświadczeń i pożądań powodujące inne odczuwanie potrzeb, inne napięcie woli. Przyszłość rodzi się w współpracy generacyjnej, splątanej z walką̨

\section{Z kategorią pokolenie historyczne powiązana jest inna kategoria społeczno-} -pedagogiczna - wiek społeczny. Jej znaczenie dyscyplinarne wyjaśniała Helena Radlińska:

Sytuację społecznąjednostki w stosunku do jej roku życia pedagogika społeczna wyraża pojęciem wieku społecznego, podobnie jak stopień rozwoju intelektualnego, właściwy dla określonego roku życia, nazwano wiekiem inteligencji, rozwoju fizycznego - wiekiem fizjologicznym.

Przy przedwczesnym podejmowaniu obowiązków mówimy o przyspieszeniu wieku społecznego, przy przeciaganiu się rodzaju pracy czy innych obowiązków poza normę - o jego opóźnieniu. Wiek społeczny wyjaśnia wiele przejawów wieku fizjologicznego i wieku inteligencji. Przyspieszenie wieku społecznego oddziałuje hamująco na rozwój psychiczny i umysłowy, opóźnienie w fazie dojrzałości pozbawia społeczeństwo cennych wartości, które tkwią w przeżywanej nie dość twórczo fazie życia.

Rozważania nad wiekiem społecznym muszą się liczyć z epokami historii, z obyczajem poszczególnych krajów i kręgów kultury, w których zachodzą wielkie różnice sytuacji społecznej jednostek. Dla pedagogiki społecznej najważniejsze są jednak normy ustalane przez obiektywne badania nad potrzebami i możliwościami faz życia.

W opracowywaniu wskaźnika stosunku wieku społecznego do wieku chronologicznego (tj. przyspieszeń czy opóźnień ujętych w symbolu liczbowym, jak iloraz inteligencji 6) dopomaga jeden ze składników pojęcia wieku społecznego: wiek prawny. Jest to określenie obowiązku i praw związanych z wiekiem chronologicznym, takich jak: obowiązek szkolny, ochrona pracy młodocianych, odpowiedzialność karna nieletnich, pełnoletniość cywilna, służba wojskowa, prawo głosowania, renta starcza.

${ }^{21}$ Tamże, s. 366-367.

${ }^{22}$ H. Radlińska, Stosunek wychowawcy do środowiska społecznego, s. 20-21. 
Rola wieku społecznego była badana na tle pełnienia obowiązku szkolnego, wchodzenia do pracy, uzyskania samodzielności i wpływów w rożnych środowiskach społecznych, ruchów młodzieży, wykolejeń i przestępczości, sytuacji starców i rencistów ${ }^{23}$.

W tworzeniu języka tożsamego dla pedagoga społecznego w ujęciu autorskim Heleny Radlińskiej istotne znacznie ma także kategoria odnosząca się do sfery aktywności człowieka, którą wyznacza przynależność zawodowa. Mowa tu o strukturze życiowej zawodu wpisującej się w katalog podstawowych pojęć pedagogiki społecznej i jej reprezentantów. W syntetycznym opracowaniu dla studentów pedagogiki społecznej autorka wyjaśniała, że:

Z punktu widzenia pedagogiki społecznej sprawy rozwoju jednostek oraz udziału ich w życiu i przetwarzaniu środowiska są rozpatrywane w całokształtach. Struktura życiowa zawodu obejmuje - obok charakterystyki czynności właściwych temu zawodowi i wymaganych przez nie uzdolnień, zasobu wiedzy i usprawnienia - również obraz warunków bytu, możliwości rozwoju i awansu, zachowania zdrowia, pomyślności rodzinnej, uczestnictwa w kulturze, związanych z pełnieniem danego zawodu.

Pojęcie struktury życiowej zawodu zostało wypracowane w badaniach nad szansą życiową, którą daje przygotowanie zawodowe, nad drogami wchodzenia do zawodów i rolą w nich poradnictwa, nad stosunkiem do pracy i losami pracowników rożnych zawodów, nad stopą życiową i wzorami społecznymi życia w wybranych środowiskach.

Poznanie struktur życiowych zawodów jest szczególnie ważne dla poradnictwa zawodowego, lekarskiego, wychowawczego, dla organizacji pracy i odpoczynku, dla spraw profilaktyki i kompensacji społecznej, spożytkowania wczasów i oświaty dorosłych ${ }^{24}$.

Proces przetwarzania rzeczywistości, przebudowy warunków życia i rozwoju ludzkiego dokonuje się w pedagogice społecznej za sprawą określonych sił. Ich odkrywanie, wspomaganie, a także uaktywnianie w twórczości służącej teraźniejszości oraz przyszłości należy do wiodących celów pedagogiki społecznej. Z tego wynikają także zadania dla pedagoga społecznego, który jest realizatorem dyscyplinarnego programu współprzetwarzania warunków życia gromadnego. Streszcza się to w zdaniu prezentującym założenia ideowe i metodyczne oraz metodologiczne pedagogiki społecznej:

Celowe wprowadzanie czynników, które nastawiając wolę ludzką, mają podtrzymywać lub zmieniać istniejące struktury; rola wszechstronnie rozpatrywanej twórczości indywidualnej i zbiorowej, zwróconej ku budowaniu jutra wedle wzoru, zależnego od sił działających i narastających; możliwość i zakres wpływu różnych czynników przebudowy - oto własne pole badań i eksperymentów pedagogiki społecznej ${ }^{25}$.

O samym pojęciu sił pisała Helena Radlińska, wielokrotnie odwołując się do różnego typu sił. $\mathrm{W}$ ich przymiotnikowej formie wymieniała ona siły jawne

\footnotetext{
${ }^{23}$ H. Radlińska, Egzamin z pedagogiki społecznej, s. 367-368.

${ }^{24}$ Tamże, s. 368.

${ }^{25}$ H. Radlińska, Stosunek wychowawcy do środowiska społecznego, s. 16.
} 
i ukryte, siły działające, narastające i wyzwalające, siły ludzkie i społeczne, siły środowiska i zbiorowe, siły narodu i siły duchowe. Wyjaśniając znaczenie pojęcia sił oraz dookreślając ich rolę w przetwarzaniu środowiska, stwierdzała ona:

Siłami w pedagogice społecznej nazywane są najogólniej czynniki działające (,siły społeczne”, w dawnej polszczyźnie ,siły działalne”), w znaczeniu węższym - uzdolnienia i cechy jednostek i grup, wyrażające się albo mogące się wyrazić w działaniu (w jakiejkolwiek dziedzinie). Pedagogika społeczna interesuje się zarówno rolą silnych, zdolnych w danej chwili do prac kulturalnych, jak i przede wszystkim zadaniami wobec słabych, których trzeba wzmocnić i usprawnić, leczyć i wspomagać. Zainteresowanie silnymi prowadzi do badań nad ruchami społecznymi, zwłaszcza nad rolą w nich zwiastunów, przodowników i realizatorów dążeń, nad wpływem idei i znaczeniem sprawności.

Ruchy samorzutne, burząc niejedną instytucję, poszukują w okresie zwycięskim oparcia na pracy poprzedników, potrzebują urządzeń - skarbnic kultury i przykładów przodowniczych, zapowiadających urzeczywistnienie dążeń.

Wspomaganie sił narastających następuje przez usuwanie przeszkód hamujących ich rozwój, przez dostarczanie podniet rozwoju, udostępnianie dorobku i uczenia sprawności.

Sprawy jednostek są stawiane w pedagogice społecznej na tle środowisk, przy czym zwraca się uwagę na spożytkowanie wartości środowiska szerszego i wzbogacanie nimi środowisk subiektywnych. Pomoc zindywidualizowana (w poszczególnych przypadkach) wiąże się z przetwarzaniem środowisk przez powoływanie do czynu sił istniejących. W działalności grupowej jednostki są wzmacniane przez wartości wytwarzane w gromadzie.

Pedagogika społeczna zajmuje się zagadnieniami powstawania i prowadzenia zespołów, czyli grup, których uczestnicy podejmują wyodrębnione czynności dla osiagnnięcia wspólnego celu ${ }^{26}$.

W celu dookreślenia kierunków projektowanych zmian oraz tworzenia koncepcji działalności orientowanej na przebudowę konieczne jest odniesienie stanu faktycznego do stanu postulowanego (zamierzonego). W tym kontekście pedagog społeczny wpisujący się w koncepcję Heleny Radlińskiej ma do dyspozycji kolejne kategorie, które są mu pomocne na poszczególnych etapach pełnionej służby. Zalicza się tu kategorie normy, wzorca oraz miernika, o których autorka pisała wprost:

Pedagogika wypracowuje pojęcie normy przy pomocy nauk o człowieku, społeczeństwie, moralności i kulturze. Za normę uważa się wielkość będącą wynikiem pomyślnego przebiegu badanego zjawiska (wzrostu, zdobywania wiedzy, sprawności itp.).

Normę należy odróżniać od wielkości przeciętnej i od wielkości typowej, stwierdzających stan w warunkach badanych, oraz od wzoru idealnego, ukazującego, jak być powinno. Norma w pedagogice społecznej liczy się z rozpoznanymi możliwościami uruchomienia sił i użycia środków. Dlatego normy są zmienne, zależnie od przemian zachodzących, w warunkach ich realizacji. Wskutek swych składników, naukowo uzasadnionych, normy nie mogą spadać tak nisko jak wielkości określone na podstawie samych tylko pomiarów.

Wzorzec jest zestawieniem norm. Obejmuje to, co jest osiagalne w danej epoce i kulturze. Zawiera w sobie realne wskazania przebudowy i kompensacji w poszczególnych dziedzinach. Przez swe składniki obiektywne wzbogaca i przetwarza wzór społeczny, powstający samorzutnie jako

${ }^{26}$ H. Radlińska, Egzamin z pedagogiki społecznej, s. 368-369. 
obraz godny szacunku i naśladownictwa. Im bardziej wzorzec liczy się z wartościami wzoru - tym łatwiej wzór uzupełnia.

Miernikiem wykonywanych zadań jest stosunek ich osiaggnięć do norm wzorca. Przy możliwości podnoszenia norm - podnoszą się mierniki.

Stosowanie norm, wzorców i mierników pozwala na określanie w pedagogice społecznej istniejących potrzeb, ich oceny i stopnia zaspokajania. Szereg badań dotyczących rozwoju ludzi i instytucji oraz typów życia w określonych środowiskach posługuje się pomocą wzorców. Przez stosowanie mierników dochodzi się do określenia wskaźnika środowiskowego w określonej dziedzinie. Był on po raz pierwszy zastosowany w studiach zespołu opracowującego „społeczne przyczyny powodzeń i niepowodzeń szkolnych" jako wskaźnik szansy ukończenia szkoły powszechnej. Odnosił się do warunków zapewniających szansę, lecz nie stanowił prognozy dla każdej jednostki żyjącej w danym środowisku. To ujęcie wiąże się najściślej z podstawowymi poglądami pedagogiki społecznej na wzajemny stosunek jednostki i środowiska.

W praktyce społecznej normy i wzorce dopomagają do planowania prac i urządzeń, mierniki - do stwierdzania roli poszczególnych czynników działań i oceny popełnionych błędów ${ }^{27}$.

W szerokim katalogu języka pedagoga społecznego na szczególną uwagę zasługują jeszcze dwie zasadnicze kategorie blisko związane z zakresem jego działalności. Chodzi tu w szczególności o diagnozę oraz profilaktykę społeczną. Można przyjąć, że w toku diagnozy ujawnia się te obszary deficytów, które wymagają podejmowania działań kompensacyjnych, ratowniczych, pomocowych, opiekuńczych czy też profilaktycznych. Jednakże diagnoza nie jest wyłącznie orientowana na obszary destytucji człowieka. Służy także odkrywaniu sił, które można angażować w procesy przetwarzania rzeczywistości życia gromadnego. W toku działań diagnostycznych pedagog społeczny odkrywa zarówno słabe, jak i silne strony środowiska społecznego. Dostrzega potencjał sił, który w dalszych etapach działań będzie stanowił potencjalne lub realne źródło wsparcia inicjatyw służących podnoszeniu jakości i kultury życia codziennego osób, rodzin, grup społecznych i całych społeczności. W syntetycznym opracowaniu Helena Radlińska wyjaśniła znaczenie obu kategorii:

Pojęcie diagnozy zaczerpnięte z medycyny oznacza w pedagogice społecznej rozpoznawanie w poszczególnych przypadkach przyczyn badanego stanu, ocenę jego objawów i możliwości przemian. Postawienie diagnozy prowadzi do planowania działalności, która ma wzmocnić badaną jednostkę czy grupę, nastawić jej wolę pokonania zła oraz dostarczyć pomocy z zewnątrz.

Profilaktyka społeczna obejmuje zapobieganie klęskom społecznym i wykolejeniom jednostek, łączy się częstokroć z profilaktyką lekarską (medycyną zapobiegawczą). Najważniejszymi dziedzinami profilaktyki są: zwalczanie pijaństwa, nierządu (prostytucji), przestępczości, chorób zakaźnych, bezdomności ${ }^{28}$.

Zagadnienie profilaktyki społecznej podejmowanej przez pedagoga społecznego łączyła Helena Radlińska z profilaktyką zdrowotną. Posługując się doświadczeniami medycyny w zakresie zarówno diagnozy, jak i profilaktyki, autorka ta

\footnotetext{
${ }^{27}$ Tamże, s. 369-370.

${ }^{28}$ Tamże, s. 370.
} 
tworzyła własny dla pedagogiki społecznej sposób rozumienia i zastosowania odpowiednich kategorii:

Profilaktyka w zakresie zdrowia i profilaktyka społeczna są ze sobą najściślej związane przy zapobieganiu chorobom, których skutki stanowią nadmierny ciężar w lecznictwie i w opiece, w ochronie macierzyństwa i pielęgnowania niemowląt. Szpitale i sanatoria stwierdzają, że leczenie jest bezpłodne, gdy pacjent powraca do złych warunków bytu i pracy, tych samych, które spowodowały choroby. Nie ma prawie przypadku, w którym nie zachodzi potrzeba racjonalnej opieki nad chorym. Domy dla rekonwalescentów, domy wypoczynkowe, przychodnie są cenione coraz bardziej. Zakres roztaczanej przez nie opieki obejmuje sprawy przekraczające granice lecznictwa, wiąże się z wychowywaniem (w leczeniu inwalidów, w zwalczaniu nałogów, we wdrażaniu wykolejonych w regularny tryb życia). Higiena psychiczna dostarcza nowego oręża wielu poczynaniom opiekuńczym ${ }^{29}$.

Zakreślony powyżej słownik pedagoga społecznego jest znacznie bogatszy i można go rozwijać w toku dalszych studiów tekstów źródłowych Heleny Radlińskiej. Decyzję o ograniczeniu pola analizy do przedstawionych kategorii należy odczytać jako zachętę do kontynuacji poszukiwań, które z pewnością przyniosą efekt $\mathrm{w}$ postaci odkrywania inspiracji w rozwoju profesjonalnym i dyscyplinarnym.

\section{Teoretyczne podstawy ujmowania rzeczywistości życia gromadnego}

Kolejnym narzędziem, do którego nawiązuję w toku kreślenia koncepcji pedagoga społecznego w ujęciu Heleny Radlińskiej, są podstawy teoretyczne stanowiące fundament dla jego działalności praktycznej. $Z$ istoty pedagogiki społecznej ujętej jako nauka praktyczna wynika potrzeba spożytkowania dorobku teoretycznego na potrzeby praktyki. Nie oznacza to jednak, że sama dyscyplina jest wolna od wysiłku intelektualnego orientowanego na generowanie dorobku teoretycznego. Przeciwnie, walor praktyczny wzmacnia tym samym powinność w zakresie teoriotwórczej aktywności naukowej, która ma w konsekwencji stanowić bazę dla działań podejmowanych w środowiskach osób, rodzin, grup społecznych czy społeczności. Tak też należy rozumieć pole aktywności samego pedagoga społecznego, który, będąc reprezentantem dyscypliny $\mathrm{w}$ deontologicznym wymiarze swej identyfikacji naukowej, winien jest korzystać z dorobku innych dziedzin i dyscyplin nauki, a zarazem tworzyć nowe teorie na użytek rozwoju własnej dyscypliny i praktyki służby ludziom. Eksponowała to Helena Radlińska: „Pedagogika społeczna korzysta z materjałów i metod wielu nauk: teoretycznych, historycznych i stosowanych, które zajmują się z różnych stanowisk człowiekiem, kulturą, życiem społecznem"30.

${ }^{29}$ H. Radlińska, Zagadnienia opieki społecznej. Ze skrzyżowań teorii i praktyki, „Praca i Opieka Społeczna" 1947, nr 4, s. 279.

${ }^{30}$ H. Radlińska, Stosunek wychowawcy do środowiska społecznego, s. 16. 
Wyrażone w 1935 r. stanowisko na temat związków pedagogiki społecznej z innymi dyscyplinami nauki poszerzyła w podsumowaniu stanowiącym przywoływany powyżej skrypt dla studentów. Wyjaśniła tam, że:

Pedagogika społeczna jest nauką praktyczną, rozwijającą się na skrzyżowaniach nauk o człowieku, biologicznych i społecznych z etyką i kulturoznawstwem (teorią i historią kultury) dzięki własnemu punktowi widzenia. Można go najkrócej określić jako zainteresowanie wzajemnym stosunkiem jednostki i środowiska, wpływem warunków bytu i kręgu kultury na człowieka w rożnych fazach jego życia, wpływem ludzi na zapewnianie bytu wartościom przez ich przyjęcie i krzewienie oraz przetwarzanie środowisk ,siłami człowieka w imię ideału”.

Dziedziny badań i przemyśleń pedagogiki społecznej rozszerzają się w związku z występowaniem w życiu nowych zagadnień. Wpływają na nie osiagnięcia zarówno myśli teoretycznej, jak i doświadczeń praktycznych.

Znajomość rozwoju człowieka pedagogika społeczna uzyskuje przy pomocy nauk biologicznych i lekarskich, psychologii (rozwojowej, wychowawczej i społecznej), nauk pedagogicznych (zwłaszcza pedagogiki leczniczej). Pedagogika społeczna, spożytkowując wyniki tych nauk, urzeczywistnia syntezę o człowieku. Przekracza postulaty wysunięte dla takiej syntezy (m.in. przez A. Carrela i J. Pietera), wiążąc sprawy życia indywidualnego i zbiorowego, poszukując sposobów dostarczania podniet rozwoju i usuwania jego przeszkód.

$Z$ rozległych spraw kultury pedagogika społeczna rozpatruje przede wszystkim warunki oraz sposoby uczestnictwa w jej dorobku i wyzwalaniu nowej twórczości. W zakresie życia społecznego spożytkowuje dane socjologii i polityki społecznej dla własnych poszukiwań. Dotyczą one przebiegów przemian społecznych i roli w nich działalności celowej. W ocenie wpływu poszczególnych czynników pedagogika społeczna sięga po pomoc historii (zwłaszcza historii kultury i wychowania, historii społecznej i gospodarczej, historii ruchów społecznych) ${ }^{31}$.

W toku pełnionej służby pedagog społeczny sięga więc po zdobycze nauk, które podobnie do pedagogiki społecznej koncentrują swą uwagę na sprawach człowieka i na środowisku jego codziennego życia. W ujęciu Heleny Radlińskiej kluczowym obszarem działań podejmowanych przez wykształconego pedagoga społecznego było odkrywanie i aktywizowanie wzmocnionych uprzednio sił ludzkich. Warto przy tym pamiętać, że istotną sprawą było dostrzeganie różnicy punktów widzenia poszczególnych nauk, których dorobek teoretyczny wspomagał praktykę służby pedagoga społecznego. Różnice te podkreślała autorka na przykładzie odniesień do wychowania stanowiącego wiodącą kategorię i zarazem obszar oddziaływania praktycznego:

Pedagogika społeczna zajmuje się przede wszystkim zagadnieniami rozpoznawania i wspomagania rozwoju sił ludzkich (fizycznych i psychicznych), jeszcze nie rozrosłych, włączania ich w twórczość dnia bieżącego i jutrzejszą. Ten pogląd prowadzi do rozróżniania t e r a ź n i e j s z o ś c i o widomym wkładzie spraw aktualnych od r z e c z y w i s t o ś c i, w której tkwią zarówno tradycje, jak i dążenia, przeżytki i możliwości.

Różnice punktów widzenia pedagogiki społecznej i innych nauk o wychowaniu są wyraźne. Zarówno socjologia, jak i filozofia wychowania są gałęziami nauk teoretycznych. Stosowanie metod tych nauk, poszukiwanie uogólnień różnią je najbardziej od pedagogiki społecznej.

\footnotetext{
${ }^{31}$ H. Radlińska, Egzamin z pedagogiki społecznej, s. 361-362.
} 
Pedagogika społeczna w przeciwieństwie do socjologii wychowania zajmuje się przebiegami i sposobami poczynań wychowawczych i rolą środowisk w związku z życiem jednostek. Wychowywanie jako celowa funkcja grup społecznych, rozpatrywana przez socjologię na tle życia grup i zachodzących przemian w ich strukturze, interesuje pedagogikę społeczną tylko jako wynik badań socjologicznych, doniosły, lecz nie wchodzący w zakres jej dociekań własnych.

Filozofia wychowania wnosi do pedagogiki społecznej ogólne poglądy, otrzymując od niej sformułowanie wielu zagadnień, dotychczas w tej filozofii nie uwzględnionych.

Dzieje wychowania, należące do nauk historycznych, interesują pedagogikę społeczną, gdy przedstawiają nie tylko doktryny pedagogiczne, lecz i praktykę wychowania kształtującą się nie tylko pod wpływem doktryn. Pedagogika społeczna wnosi do historii pojęcia przez siebie wypracowane, które wpływają na poszukiwanie czynników kształtujących myśl i działanie, dostrzeżonych z punktu widzenia pedagogiki społecznej.

W zakresie praktycznych nauk o wychowaniu pedagogika społeczna w porównaniu z tzw. pedagogiką ogólną ma szerszy zasięg zainteresowań, traktuje szkołę jako jedną, nie zawsze najważniejszą instytucję wychowująca, częściowo tylko zajmuje się dydaktyką (zwłaszcza dydaktyką dorosłych), obejmuje sposoby nie tylko wprowadzania i uczenia, lecz również przemiany środowiska, w którym odbywa się działalność wychowawcza.

Teoria wychowania fizycznego wraz z higieną dostarczają pedagogice społecznej danych o rozwoju fizycznym w okresach dzieciństwa, młodzieńczości i młodości. Nawzajem otrzymują wzorce społeczne bytu, konieczne dla osiaggnięcia stanu uważanego za normalny.

Od psychologii wychowawczej pedagogika społeczna bierze wyniki badań nad rozwojem i mierzeniem jego wyników, przy ich ocenie wnosi doświadczenia własne z poszukiwań warunków umożliwiających i hamujących rozwój.

W zestawieniu z pedagogiką leczniczą pedagogika społeczna, korzystając z badań nad zahamowaniami i skrzywieniami rozwoju indywidualnego, wprowadza dane o ich społecznych przyczynach, o możliwościach i sposobach zapobiegania im i wyrównywania.

Korzystanie $\mathrm{z}$ nauk pedagogicznych nie wystarcza w ujmowaniu spraw wychowania przez pedagogikę społeczną. Zajmując się zarówno najwcześniejszymi (od poczęcia), jak i późniejszymi okresami życia (łącznie ze starością), pedagogika społeczna musi sięgać bezpośrednio do nauk biologicznych i lekarskich.

W badaniach nad stawianiem celów wychowania i zasięgiem czynności wychowawczych pedagogika społeczna współdziała z nauką o moralności i polityce społecznej, w zainteresowaniach środowiskiem społecznym włącza się do prac socjologii i demografii, zawsze wychodząc i powracając do wybranego punktu widzenia, co stanowi o jej samodzielności i umożliwia świadczenia wzajemne.

Poszukując odmienności dyscyplin naukowych, należy pamiętać o ich związkach i jedności w obrębie nauki, która wprowadza podziały tylko w celu umożliwienia pogłębionych badań i wypracowania metod najwłaściwszych w danych zakresach. Podziały nie wykluczają przenikania zagadnień, wspólności w poszukiwaniu prawdy, korzystania z wytworzonych narzędzi ${ }^{32}$.

W kontekście prezentowanych związków pedagogiki społecznej z dorobkiem teoretycznym innych nauk warto podkreślić, że już w czasie dyscyplinaryzacji dokonującej się za życia Heleny Radlińskiej wyodrębniły się fundamentalne działy polskiej pedagogiki społecznej. Wyznaczały one tym samym obszary aktywności teoriotwórczej i praktyki pedagogów społecznych. Ów dorobek teoretyczny określony został przez autorkę w następującej syntezie:

${ }^{32}$ Tamże, s. 363-364. 
Te oria pracy społec znej zajmuje się rozpoznawaniem warunków, w których zachodzi potrzeba ratownictwa, opieki, pomocy, zabezpieczenia oraz sposobów odnajdywania sił ludzkich i organizowania ich w celach twórczości życiowej. Na tym tle powstają nowe specjalizacje: pedagogika opiekuńcza i nauka o sprawach młodzieży.

Te or i a ów iaty dorosły ch obejmuje zagadnienia potrzeb w zakresie kultury duchowej i możliwości. Rozpatruje sposoby dostarczania podniet rozwoju, dopomagania jednostkom i grupom w wykonywaniu zadań, które życie stawia przed nimi, uzupełniania ruchów oświatowych przez organizację urządzeń, systematyzuje sposoby i wyniki kształcenia oraz spożytkowania wczasów. Na tle tych badań, doświadczeń i rozważań kształtuje się i wyodrębnia pedagogika pracy.

Historia pracy społecznej i oświatowej poszukuje czynników ewolucji urządzeń społecznych i ich powiązań, trwałości i zmienności dążeń i form, skutków celowych oddziaływań i roli samorzutnych zjawisk na szerszym tle życia społecznego i gospodarczego ${ }^{33}$.

Podkreślając związek teorii z praktyką dokonujący się w pedagogice społecznej, można zakreślić obszary działalności podejmowanej przez pedagoga społecznego. Są one ściśle związane z odpowiednimi źródłami teoretycznymi tworzonymi na potrzeby owej aktywności profesjonalnej, która stanowi istotny czynnik wyzwalający proces zmian orientowanych na rozwój i podnoszenie kultury oraz jakości życia codziennego osób, rodzin, grup społecznych i społeczności. Zaliczyć tu można w pierwszej kolejności służbę społeczną i odpowiadającą temu teorię służby społecznej rozwijaną przez Helenę Radlińską w ramach tworzenia metodycznych podstaw działalności podejmowanej w obszarach opieki, ratownictwa, pomocy, kompensacji, profilaktyki itp. Kolejnym obszarem znajdującym swe odniesienie do teoretycznych podstaw pedagogiki społecznej i innych nauk jest sfera oświaty dorosłych wraz ze szczególnymi obszarami aktywności kulturalnej, czytelniczej, wypoczynkowej, profilaktycznej itp. Służba pielęgniarska to także istotne zagadnienie, które dla pedagoga społecznego jest o tyle ważne, o ile odwołuje się do partnerstwa w rozwiązywaniu problemów społecznych ${ }^{34}$. Przyjęte przez Helenę Radlińską założenie praktycznej funkcji budowanej dyscypliny naukowej wyznaczało określone jej role:

Jak wszystkie nauki praktyczne pedagogika społeczna ukazuje możność przystosowania zdobyczy teorii do zaspokajania potrzeb ludzkich. Nie daje bezpośrednich wskazań, tylko wiedzę o zasadach celowego działania. Do działaczy należy świadome stosowanie zasad. Potrzebne są ku temu prócz wiedzy doświadczenie własne, wola i intuicja.

Zasady celowego działania, wypracowane w pedagogice społecznej, mają znaczenie nie tylko dla pracy społecznej i oświatowej, lecz również dla wielu dziedzin życia, w których wychowanie stanowi lub stanowić powinno jeden z czynników świadomego oddziaływania. Dziedziny te są

${ }^{33}$ Tamże, s. 362.

${ }^{34}$ Szerzej o teoriach i ich zastosowaniu w toku praktyki służby społeczno-pedagogicznej zob. szerzej: H. Radlińska, Planowanie pracy wychowawczej na tle środowiska, ,Ruch Pedagogiczny” 1933/1934, nr 5, s. 157-168; taż, Zadania pracy kulturalnej, „Kultura Polski” 1917, z. 1, s. 1-5; taż, Program pracy oświatowej, „Kultura Polski” 1917, z. 7-9, s. 426-428; taż, Pedagogika spoleczna, s. 219 i n., 305 i n., 362 i n. 
liczne i obejmują m.in.: administrację terytorialną i gospodarczą, organizację pracy, budownictwo, zapobieganie chorobom i przestępczości, lecznictwo, sądownictwo.

Wykształcony pracownik społeczny staje do pomocy ustawodawcom i twórcom planów: organizatorom, architektom, lekarzom, sędziom, wnosząc wiedzę o potrzebach człowieka i siłach, które mogą być powołane do ich zaspokajania, o sposobach wychowywania twórców i użytkowników urządzeń istniejących i wytwarzanych ${ }^{35}$.

Fragment ten oddaje nie tylko szeroki zakres współdziałania pedagoga społecznego w przestrzeniach służby podejmowanej z myślą o przebudowie warunków życia gromadnego, ale odsłania także perspektywę, z jaką kreślona była polska pedagogika społeczna u progu XX w. Nie ma tu mowy o konstruowaniu dyscypliny zawężającej czy też atomizującej pole aktywności profesjonalnej. Przeciwnie, Helena Radlińska podkreślała uniwersalną i wielowymiarowa, a zarazem interdyscyplinarną perspektywę pedagogiki społecznej, której reprezentanci są gotowi do współtworzenia dobra społecznego w kooperacji z przedstawicielami innych dyscyplin i profesji społecznych, technicznych, medycznych, administracyjnych itp.

\section{Metodologiczne założenia społeczno-pedagogicznego poznawania rzeczywistości życia codziennego}

Teoretyczne modele rzeczywistości służące zrozumieniu, wyjaśnieniu lub przewidywaniu stanów, zdarzeń bądź procesów zachodzących w przestrzeniach stanowiących pole zainteresowania pedagoga społecznego są użyteczne w tworzeniu systemowych podstaw działalności praktycznej. Naukowy rozwój dyscyplinarny stanowi tu nieodzowny komponent aktywności podejmowanej w środowisku akademickim pedagogów społecznych. Jednakże jest on równoważony na poziomie deontologicznym troską o doskonalenie metodyki służby, do której pedagog społeczny jest determinowany powinnością wynikającą z charakteru nauki praktycznej. Pomiędzy zaangażowaniem teoriotwórczym i praktyką działalności profesjonalnej można wyodrębnić na poziomie analitycznym przestrzeń metodologiczną. Jest ona integralnie złączona z codzienną działalnością pedagoga społecznego odgrywającego role zarówno praktyczne, jak i akademickie. Podkreślała to Helena Radlińska, pisząc o przenikaniu się działania i badania w procesie podejmowanej służby:

Badanie i działanie są ze sobą splecione w wychowaniu szczególnie mocno: skuteczna praca wychowawcza opiera się na ciaggłej obserwacji, planowaniu i ocenie.

Poszukiwanie dróg w gąszczu krzyżujących się spraw, wśród walk o miejsce dla nich prowadzonych z namiętnością i uporem, odbywa się za pomocą nauki. Zapoznanie się z dorobkiem nauk pomocniczych dla wychowania, poczynienie (pod umiejętną kontrola) prób badań - objektywizuje spojrzenie.

\footnotetext{
${ }^{35}$ H. Radlińska, Egzamin z pedagogiki społecznej, s. 365-366.
} 
Praca poznawcza pedagoga, służąca życiu, nie zawsze jest dość umiejętna, dość ścisła, by wnosić wkład do nauki. Dlatego działacz, posługujący się dla swych celów badaniem, powinien poznać na przykładzie, czem jest badanie naukowe, i zdobyć się na skromność w ocenie swych własnych poczynań. Powinien zwłaszcza poznać zbliska najbardziej charakterystyczną cechę badania naukowego - uczciwość intencyj i wykonania, najwyższą miarę uczciwości, na jaką się może zdobyć człowiek. Ta cecha wyróżnia pracę naukową od wszelkiego nadużywania poszczególnych metod, w nauce wyrobionych, jako pomocy technicznej dla celów ubocznych ${ }^{36}$.

Kontynuując wywód stanowiący swoiste uzasadnienie kształcenia kompetencji metodologicznych u pedagogów realizujących misję społecznego rozwoju, autorka zwracała uwagę na aksjologiczny i deontologiczny wymiar badania naukowego. Nawiązanie do etyki badań społecznych wpisuje się w szerszy kontekst sięgania po metody poznania rzeczywistości, które są wytworem aktywności naukowców i służą generowaniu wiedzy użytecznej dla działaczy przetwarzających określone przestrzenie życia gromadnego. Szczególną rolę odgrywa tu cecha badacza i zarazem działacza sięgającego w toku swej aktywności po efekty dorobku metodologicznego - uczciwość. Uwagi czynione niemal 100 lat temu są uniwersalne i stanowią źródło inspiracji dla współczesnych profesjonalistów eksplorujących rzeczywistość społeczną:

Uczciwość naukowa wyklucza poszukiwanie uzasadnień tezy zgóry powziętej. Nakazuje uznać za jednakowo wartościowe odpowiedzi ,tak” i „nie”, wynikające z badań, choćby to „nie” burzyło gmach radosnej ułudy lub zmuszało do zmiany wygodnej drogi na nieznaną, niepewną ścieżynę.

Uczciwość - zmusza do wielostronnych poszukiwan, powtarzania prób i doświadczeń i dokładnej oceny warunków, w których się odbywają. Potrzebuje rozwagi, czasu, nieprzewidzianego wymiaru trudu. Nakazuje powiedzieć całą poznaną prawdę, także prawdę o dostrzeżonych błędach własnych i niedoskonałości użytych metod.

Badanie naukowe wymaga rozległej kultury duchowej, na tle której formułują się pytania. Dla celów nauk stosowanych w skład tej kultury wchodzi również doświadczenie życiowe, wspomagane przez sztukę obserwowania.

Z punktu widzenia pedagogiki społecznej najważniejszem zagadnieniem jest poszukiwanie czynników, rozbudzających siły ludzkie, rozpoznawanie ich oddziaływań jako bodźców postępowania.

Samo gromadzenie faktów, opisywanie warunków, w których zachodzą jakieś zjawiska, nie jest pracą naukową - o ile badacz nie potrafi postawić zagadnień, ukazać związków pomiędzy faktami, ocenić ich wagi.

Obraz tego, co się dzieje, może być cenny jako materiał naukowy tylko wówczas, gdy jest dokonany najściślej uczciwie i wszechstronnie. Materiały zyskują wartość, gdy mogą być sprawdzane i rozmaicie szeregowane ${ }^{37}$.

Etyka poznania społeczno-pedagogicznego, które z założenia ma służyć twórczości orientowanej na przebudowę warunków życia gromadnego, stanowi istotny komponent metodologicznego programu opracowanego przez Helenę Radlińską dla pedagogów społecznych. Autorka ukazała równocześnie, że nie

\footnotetext{
${ }^{36}$ H. Radlińska, Stosunek wychowawcy do środowiska społecznego, s. 72-73.

${ }^{37}$ Tamże, s. 73-74.
} 
każde badanie nosi znamiona naukowego poznania rzeczywistości. Podkreślała jednak, że dla celów planowanej działalności społeczno-pedagogicznej każdy rodzaj zaangażowania badawczego jest cenny. Niesie ze sobą potencjał aktywizujący siły działacza do przekraczania granic poza własny krag pola widzenia, rozbudza ciekawość poznawcza, multiplikuje wiedzę o sprawach ludzkich i zarazem wyzwala zaangażowanie w problemy przeżywane przez ,innych”. Identyfikacja z zagadnieniami stanowiącymi istotę życia człowieka czyni z działacza badającego określone wycinki rzeczywistości podmiot zorientowany na poszukiwanie rozwiązań dla diagnozowanych trudności, dysfunkcji czy problemów. Ważna jest przy tym umiejętność badawcza, aby przyszłe koncepcje, modele i plany działań praktycznych miały swe oparcie w dobrym rozpoznaniu i zrozumieniu stanu faktycznego, włącznie z usytuowaniem przyczyn i ich determinującej roli dla człowieka żyjącego w eksplorowanym środowisku.

Z etycznym wymiarem poznania, które ma służyć działaniu, wiąże się także zagadnienie prawdy, które akcentowała Helena Radlińska:

Rozpoznawanie rzeczywistości dla celów działania nie jest jednoznaczne z umiejętnym badaniem, byłoby jednak bezpłodne, gdyby nie posiadało pewnych cech charakterystycznych dla badań naukowych. Najważniejszą z nich jest poszukiwanie prawdy, choćby była ona sprzeczna z życzeniami działacza. Drugą i niemniej konieczną - zainteresowanie splątaniami w jakich występują zjawiska życia społecznego (nieraz na przekór obmyślanemu programowi) ${ }^{38}$.

Etyczny uniwersalizm zarysowany w przywołanym fragmencie potwierdza perspektywę orientująca pedagoga społecznego w przestrzeni wartości, reguł i zasad postępowania poznawczego. Niezależnie od charakteru poznania, jego celowości czy przewidywanych rezultatów ważne jest w prezentowanym tu podejściu, aby profesjonalista akademicki lub praktyk służby społeczno-pedagogicznej kierował się w eksploracjach dążeniem do odkrywania prawdy, uczciwością, rzetelnością itp. Etyczne zobowiązania nie wygasają z chwilą zmiany priorytetów, celu poznania (rozpoznania) rzeczywistości czy jego charakteru. Są wciąż obecne w polu teorii oraz praktyki pedagoga społecznego.

Wyrobienie badawcze pedagoga społecznego, o którym wielokrotnie pisała Helena Radlińska, można traktować jako zachętę dla praktyków działających w polu służby społeczno-pedagogicznej. W syntezie zawartej w opracowaniu Egzamin z pedagogiki społecznej autorka część uwagi poświęca zagadnieniom metod stosowanych w badaniach naukowych. Fragment ten poprzedza prezentacją samego badacza, którym jest tu pedagog społeczny umiejscowiony w polu poznania dyscyplinarnego. Wskazując indywidualne cechy badacza, pisze ona, że:

Dla postawienia pytań-zagadnień, na które ma się poszukiwać odpowiedzi, konieczne są: ogólna kultura umysłowa badacza, jego doświadczenie, oczytanie, zainteresowanie.

${ }^{38}$ H. Radlińska, Spojrzenie na rzeczywistość, „Oświata i Kultura” 1946, nr 5-6, s. 248. 
K. Krzeczkowski podkreśla, że w naukach praktycznych osobowość badacza odgrywa szczególnie doniosłą rolę, gdyż intuicja, wyczulona przez zbliżenie się do spraw życia, wskazuje drogę poszukiwań.

Wobec charakterystycznego dla pedagogiki społecznej wielostronnego rozpatrywania związków wzajemnych człowieka i środowiska badacz powinien mieć rozległe przygotowanie naukowe i doświadczenie życiowe. W stosunku do siebie, jako narzędzia własnej pracy, powinien się zdobyć na obiektywną ocenę własnych cech, możliwości i własnego punktu widzenia. Zwrócić przy tym ma uwagę nie tylko na posiadane wiadomości i umiejętności zdobywania potrzebnej wiedzy, lecz również na sposób postrzegania, na wyćwiczenie uwagi, aby się stała podzielna (bez rozpraszania się) i dowolna, na wyrabianie pamięci wiernej, trwałej i usłużnej oraz wyobraźni społecznej, kojarzącej spostrzeżenia i przemyślenia.

Stawianie zagadnień, które ma się rozwiązać w podejmowanych poszukiwaniach, jest ściśle związane z pracą nad sobą. Wchodzi do niej również zdobywanie sprawności ułatwiających poszukiwanie odpowiedzi na postawione pytania. Należą do nich, przykładowo - umiejętność sporządzania bibliografii i posługiwania się piśmiennictwem, opanowanie techniki korzystania z bibliotek, archiwów, muzeów, notowania, szkicowania, wyraźnego pisania, używania maszyn (do pisania, liczenia, powielania), fotografowania. Dla zdobywania tych i innych sprawności bardzo ważne jest tworzenie już w czasie studiów własnego warsztatu naukowego ${ }^{39}$.

Kontynuując wypowiedź, cytowana autorka wskazała na złożoność zagadnień i problemów badawczych podejmowanych w toku poznania przez pedagogów społecznych. Ich wielowymiarowość i bogactwo oraz wielokrotnie podkreślana różnorodność uzasadnia niejednokrotnie słuszność powoływania zespołów badawczych. Wynikają stąd bowiem zarówno walory merytoryczne, jak i społeczne, które prowadzą do tworzenia więzi i relacji osobowych wzbogacających równocześnie pole widzenia poznawanej rzeczywistości:

Zagadnienia pedagogiki społecznej wymagają często opracowań zespołowych. Wspólne przygotowanie się do działalności poznawczej wzbogaca problematykę i pozwala na korzystanie z wiedzy i doświadczeń uczestników zespołu. Współpraca w poszukiwaniach pozwala na szerszy ich zasięg.

Dla prowadzenia prac zespołowych konieczne jest wytworzenie odpowiednich warunków. Należą do nich: kompetentne kierownictwo naukowe, sprawny sekretariat techniczny, stałe zebrania informacyjne i referatowe, wyćwiczenie uczestników w słownictwie tematu i w potrzebnych technikach oraz drobiazgowa kontrola oddawanych robot. Kierownictwo zespołu, rozdzielające i skupiające poszczególne zadania, powinno wiedzieć, co w pracy zbiorowej musi być dziełem indywidualnym i jakie jest znaczenie wkładów indywidualnych w pracy zbiorowej. Przykładem techniki i wyników badań zespołowych jest książka Społeczne przyczyny powodzeń i niepowodzeń szkolnych ${ }^{40}$.

Odwołanie do monografii stanowiącej podsumowanie badan prowadzonych w okresie międzywojennym warto traktować jako zachęte do wnikliwej lektury, z której uważny czytelnik będzie mógł czerpać inspiracje dla planowanych w XXI w. projektów badawczych. Zasadność owej zachęty jest szczególna, gdy zamierzenia eksploracyjne mają być podejmowane $\mathrm{w}$ polu problematyki

\footnotetext{
${ }^{39}$ H. Radlińska, Egzamin z pedagogiki społecznej, s. 371-372.

${ }^{40}$ Tamże, s. 372.
} 
społeczno-pedagogicznej. Jest ono specyficzne dla dyscypliny i charakteryzuje się tym, iż:

W pedagogice społecznej występuje wyraziście zainteresowanie indywidualizacją i uogólnieniem. Problemy in d y w i d u a l i z a c j i są rozwiązywane w przedstawianiu potrzeb, losów, cech jednostek, urządzeń, instytucji. Przez porównywanie szczegółowych charakterystyk jednostkowych dochodzi się do odnalezienia istniejących w nich różnic i podobieństw, co pozwala na unikanie błędów w zestawianiu danych statystycznych oraz na u o g óln i a n i e roli badanych czynników, przebiegu zjawisk itp. Uogólnianie naukowe opiera się na rozpoznawanych przypadkach, nie może wprowadzać ubocznych motywów ocen i nie dopuszcza zasięgu zbyt szerokiego w stosunku do posiadanych materiałów. Typowe pod tym względem były badania nad drugorocznością.

Inną cechą pedagogiki społecznej jest badanie przebiegu zjawisk i wyjaśnianie w ten sposób stwierdzanych stanów. Wśród zjawisk badanych w ich przebiegu najważniejsze jest oddziaływanie wzorca. Postawione już zagadnienia skierowane są ku badaniu, jakie braki samorzutnych wzorów społecznych kompensują wzorce, co zapewnia im moc oddziaływania i jakie znaczenie posiada stosunek wzorca do wzoru społecznego, nowego wzorca do dawniejszych. Dalszym zagadnieniem jest przenikanie się różnorodnych spraw rozgrywających się wokoło ludzi, odnajdywanie wspólnych składników w przeciwstawnych sobie wzorcach i wpływ tej wspólności na powodzenie lub niepowodzenie poczynań, które nadają barwę charakterystyczną teraźniejszości każdego czasu.

Poszukując mierników trwałości i mocy poszczególnych elementów kultury, roli i znaczenia czynników przebudowy, pedagogika społeczna szuka odpowiedzi, jak cele działalności są stawiane oraz jak są urzeczywistniane i - zależnie od użytych środków - przekształcają się w życiu wszechstronnie twórczym.

Ten typ dochodzeń był stosowany w opracowywaniu prognostyczności testów, wyników porad zawodowych, sytuacji dawnych uliczników, losów wykolejonych, którzy doznali pomocy lub znaleźli się w innych warunkach, roli urządzeń, które przetrwały zmiany ustrojowe.

Wymienione cechy wynikają z założeń teoretycznych poszukiwania czynników przemian. Wpływają na używanie i wytwarzanie technik gromadzenia, porządkowania i opracowywania materiałów $w^{41}$.

Kreślony obraz koncepcji pedagoga społecznego w ujęciu Heleny Radlińskiej był inspiracją dla przybliżenia metodologicznych założeń dyscypliny, w obrębie której badacze i zarazem działacze podejmują różnorodne zagadnienia występujące w eksplorowanej rzeczywistości. Autorka nie poprzestała na wskazaniu ogólnych założen, ale zarysowała konkretne sposoby gromadzenia i opracowania materiału empirycznego wywodzonego z toku badań. Wyróżniając typy materiałów, z których badacz korzysta i które wytwarza, opisywała również drogi naukowego poznania, odnosząc się zarówno do badań ilościowych, jak i jakościowych:

Rozróżniamy materiały istniejące i wytwarzane. Do pierwszych są zaliczane d o k u m e n t y życia osobistego i społecznego (akta, listy, pamiętniki, wyniki spisów itp.).

Przy gromadzeniu materiałów i s t n i e j ą c y c h niezbędna jest znajomość licznych zbiorów, orientowanie się w sposobach podziału, przechowywania i udostępniania dokumentów. Książki z zakresu metodologii i informacyjne ułatwiają poszukiwania. Przy zbieraniu materiałów należy robić wyciąi, notatki, cenniejsze akta najlepiej jest fotografować.

${ }^{41}$ Tamże, s. 372-373. 
Materiały wytwarzane powstają z woli badającego dzięki obserwacjom, lustracjom i doświadczeniom.

O b s e r w a c j a przeprowadzona jest bądź swobodnie, aby się zorientować w splocie składników obserwowanej sytuacji czy zjawisk, bądź też planowo w celu uchwycenia wybranych wątków. W obserwacji swobodnej szczególne znaczenie posiada obserwacja „przeżywana”, tj. w zespoleniu z obserwowanymi, niejako ich oczyma. Niebezpieczeństwa obserwacji usuwa częściowo poznanie własnego punktu widzenia i korzystanie z różnorodnych dokumentów.

Z obserwacją planową łączy się wy wi a d środowiskowy, obejmujący wszelkie sposoby poznawania sytuacji społecznej osób, grup i urządzeń na tle ich środowisk (zbieranie dokumentów, autopsja, czyli oglądanie miejsc, na których rozgrywają się badane sprawy), rozmowy z ekspertami, tj. znawcami danych spraw, oraz rozmowy z uczestnikami przeżyć i wydarzeń, zbierające ich wspomnienia, oceny i postulaty. Wywiad środowiskowy jest możliwie wszechstronny i obiektywny. Ma oświetlić stosunki, sam przez się nic nie wnosi (w przeciwieństwie do wywiadu opiekuńczego).

Wywiady dokonywane we wszystkich dziedzinach życia badanego środowiska, zazwyczaj zespołowo, stanowią przegląd zwany $1 \mathrm{ustracj}$ a. Lustracje w pedagogice społecznej są nastawione na odnajdywanie czynników przebudowy, stanowią podstawę planowania.

Metodą częstokroć nadużywaną jest a n k i e ta (ustna, piśmienna lub półpiśmienna) przeprowadzana planowo w celu oświetlenia wybranych spraw. Ankieta posługuje się zazwyczaj kwestionariuszem, który (zwłaszcza w ankietach masowych) powinien być starannie wypróbowany i ustalony (cechowany).

Do materiałów wytwarzanych należą również listy, pamiętniki, autobiografie pisane na wezwanie. Nieraz jest przy tym stosowana forma konkursu.

Używając rożnych sposobów wytwarzania materiałów, należy dokładnie zdawać sobie sprawę z okoliczności i z celu ich gromadzenia, z postawy własnej i z postaw rozmówców i korespondentów. Należy również pamiętać, że niejedną (czasem najważniejszą) wiadomość uzyskuje się ubocznie, mimochodem, dlatego w czasie gromadzenia materiałów uwaga powinna być napięta i wyobraźnia rozbudzona.

D o ś w i a d c z e n i a w pedagogice społecznej są rzadko przeprowadzane z powodu trudności znalezienia warunków porównywalnych. Polegać one mogą na wprowadzaniu określonego czynnika kompensacji i badaniu jego wpływów albo użyciu wybranych metod postępowania, innych w paru podobnych okolicznościach, i stwierdzeniu ich wartości. Pedagogika społeczna posługuje się wynikami doświadczeń klinicznych, laboratoryjnych, dydaktycznych - o ile zawierają one dane o sytuacjach społecznych, w których były dokonywane.

W gromadzeniu i wytwarzaniu materiałów oraz w dokonywaniu doświadczeń w dotychczasowych badaniach pedagogiczno-społecznych Wolnej Wszechnicy Polskiej i Uniwersytetu Łódzkiego przestrzegana była zasada liczenia się z badanymi, uświadomiania im celów badań, wkraczania w sprawy osobiste tylko dla dobra i za zgodą jednostek. Etyka zawodowa pedagoga społecznego ma wiele wspólnego z etyką lekarza ${ }^{42}$.

Ostatni akapit cytowanej wypowiedzi Heleny Radlińskiej w sposób szczególny odnosi się do etycznych aspektów poznania społeczno-pedagogicznego. Warto i w tym kontekście w szczególny sposób podkreślić spójność dyscyplinarną pedagogiki społecznej i medycyny. Obie nauki odwołują się bowiem do zasady Hipokratesa - primum non nocere, która w deontologicznym wymiarze może być traktowana jako instytucja bezpieczeństwa metodologicznego. Chroni bowiem osoby uczestniczące $\mathrm{w}$ projektach badawczych przed dehumanizacją

${ }^{42}$ Tamże, s. 373-374; por. H. Radlińska, Stosunek wychowawcy do środowiska społecznego, s. $75-90$. 
i uprzedmiotowieniem relacji badacz-badany. Bez wattpienia nie jest to gwarancja zachowania perspektywy humanistycznej w toku badań. Jednakże odwołanie do idei włączania uczestników badań w założenia metodologiczne oraz cele podejmowanych badań, jak również ekspozycja wolicjonalnego wymiaru udziału w samym projekcie badawczym należy traktować jako urzeczywistnianie idei podmiotowości i szacunku dla godności osobistej człowieka, który współuczestniczy w poznawaniu określonego wycinka rzeczywistości.

Kwestią szczególnie ważną zarówno z perspektywy interesu badacza, jak i ostatecznych wyników prowadzonych badań jest zagadnienie porządkowania oraz krytyki materiału empirycznego pozyskiwanego w toku eksploracji. Pisała o tym Helena Radlińska, zwracając uwagę na fakt, że:

W ciągu gromadzenia materiały powinny być porządkowane i oceniane. Na mocne podkreślenie zasługują wskazania wynikające z zasad już omówionych, które pokrótce można by ując jako zasady uczciwości badacza. Wyraża się ona w sumiennej kontroli własnej postawy. Przede wszystkim w gotowości przyjęcia wyników badań bez względu na to, czy są zgodne z poglądami własnymi, wynikającymi z życzeń i dążeń. $Z$ tego punktu widzenia ocenia się materiały wytwarzane, które mogą posiadać wady organiczne, wynikłe z warunków ich powstawania.

Porządkowanie materiałów ma ułatwić ich spożytkowanie, dlatego powinny być szeregowane wedle potrzeb opracowywanego tematu. W pedagogice społecznej najczęściej są używane układy wedle płci i w jej obrębie wedle wieku badanych albo wedle miejscowości, wedle instytucji. Układ alfabetyczny jest cenny tylko w skorowidzach. O technice mówi skrypt osobny ${ }^{43}$.

Przy krytyce należy porównywać dane, których dostarczyły materiały. Szukanie w nich odpowiedzi na postawione pytania ułatwi precyzowanie zagadnień. Posługiwanie się wzorcem i obmyślanie mierników dopomaga do stwierdzenia braków, wskazuje kierunek dalszych poszukiwań.

W badaniach zespołowych, których wyniki opracowywane są indywidualnie, szczególnie ważna jest krytyka otrzymanego materiału. Gdy posiada ona wady organiczne, należy zaniechać zamiaru opracowania ${ }^{44}$.

Uwrażliwianie pedagoga społecznego na sprawę krytycznego podejścia do wytworzonych w toku pracy badawczej materiałów zasługuje na odrębną analizę. Powodów jest kilka, z których na pierwszy plan wysuwają się diagnozowane współcześnie tendencje akceleracji rozwoju naukowego w obszarach nauk społecznych i humanistycznych. Eksponowany nierzadko kryzys nauki, w tym humanistyki zdaje się skutkować raczej krytykanckim niż krytycznym podejściem do tej kwestii. Ograniczanie przestrzeni i autonomii naukowej jej reprezentantom, zobowiązanie do osiagania efektów w krótkich interwałach czasowych, parametryzacja i tzw. ,punktowe modele” uprawiania nauki wydają się zaprzeczeniem istoty uniwersytetu jako instytucji zorientowanej m.in. na poszukiwanie prawdy o rzeczywistości, tworzenie wiedzy o świecie i sposobach doskonalenia

${ }^{43}$ H. Radlińska, Technika pierwszej pracy naukowej, Łódź 1950; skrypt wydany przez Koło pedagogów społecznych Uniwersytetu Łódzkiego.

${ }^{44}$ H. Radlińska, Egzamin z pedagogiki społecznej, s. 374-375. 
określonych jego fragmentów. Sprawą otwartą pozostanie więc kwestia krytycznego podejścia do wytwarzanych materiałów. Kluczowe wydaje się godzenie interesów z możliwościami i ograniczeniami formalnymi zakreślanymi administracyjną formułą zarządzeń, rozporządzeń czy ustaw. Wolność i swoboda pracy naukowej doznają licznych ograniczeń, w których założenia dotyczące m.in. krytyki efektów własnej aktywności zdają się wymagać sił wewnętrznych i moralnej odpowiedzialności oraz wytrwałości w służbie akademickiej.

\section{Metodyka pracy pedagoga społecznego - w stronę praktyki służby ludziom}

O ile operacjonalizacja języka, budowanie teoretycznych i metodologicznych podstaw uprawiania nauki jest dla pedagoga społecznego istotne w kontekście dyscyplinarnym, o tyle generowanie metodycznych modeli służy praktyce działalności społecznej podejmowanej w różnorodnych przestrzeniach życia gromadnego. Odwołując się jednak do koncepcji stworzonej przez Helenę Radlińską, wszelkie podziały należy traktować wyłącznie umownie. Służą one celom analitycznym, zaś całościowa perspektywa ujmowania zagadnień społeczno-pedagogicznych wydaje się w pełni uzasadniona. Świadczą o tym liczne fragmenty wypowiedzi autorki, która łącząc badanie z działaniem oraz teorię z praktyka, podkreślała holistyczną cechę pedagogiki społecznej. Jest to bowiem dyscyplina naukowa, która pożytkuje zdobycze akademickie dla praktyki, a równocześnie z praktyki wywodzi skutki dla rozwoju naukowego. Egzemplifikacją tego może być podejście do działalności opiekuńczej, która jest, zdaniem przywołanej badaczki, oparta na dobrej diagnostyce rzeczywistości:

Prowadzenie badań należy do najpilniejszych spraw opieki społecznej. Potrzebują one poparcia, które powinno się opłacić przez wzmożenie celowości w pracy opiekuńczej i zmniejszenie kosztów czynności zbędnych. Poparcie polega nie tylko na dostarczaniu instytutom badawczym środków na prowadzenie dobrze wyposażonych warsztatów, lecz również na zapewnienie im możliwości badań. Jest ona głównym warunkiem odpowiedzialności za zdobywanie prawdy ${ }^{45}$.

Kontekst wykorzystania doświadczeń praktycznych w pracy teoriotwórczej akcentowała Helena Radlińska w materiałach autobiograficznych, gdy wspominała swe zaangażowanie w prace społeczne i wymianę doświadczeń na polu międzynarodowym:

Z każdego z częstych pobytów za granica, ze współpracy organizacyjnej w kilku radach międzynarodowych czerpałam dla siebie niewątpliwie nie wszystko, co można było uzyskać. Brałam to, co mi było potrzebne dla wypracowywanej teorii pedagogiki społecznej. Były to przede wszystkim pojęcia wytworzone w służbie społecznej. [...]

${ }^{45}$ H. Radlińska, Pedagogika społeczna, s. 338. 
Nieraz w poprzednich Listach wspominałam o znaczeniu przeżytego i widzianego w kształtowaniu się moich pojęć. Należałoby dodać: przeżyć zachodzących w pracy, nawet fizycznej, którą niezmiernie cenię i lubię. Nieraz powtarzałam, że do wprowadzenia uczniów w teorię nauki praktycznej upoważniają mnie studia, długie wpatrywanie się w życie i wykonywanie wielu robót najprostszych... ${ }^{46}$

Całościowe spoglądanie na sprawy działalności podejmowanej przez pedagoga społecznego nie ograniczało się wyłącznie do łączenia teorii z praktyką i badaniem rzeczywistości. W odniesieniu do każdej ze wskazanych aktywności holizm miał równie silne zakorzenienie. Przykładem może być koncepcja kształcenia pedagoga społecznego jako formuła uniwersalna, nadająca fundamentalne kompetencje, wiedzę i umiejętności. Ta baza stanowiła filar dalszej specjalizacji, ale nie ograniczała się do wąskiej perspektywy oglądu spraw społecznych, które z natury swej są złożone i wielowymiarowe. Podejście takie oddaje fragment poświęcony praktyce służby społecznej:

Nie mieliśmy dotychczas czynników życia społecznego, których obowiązkiem byłoby czuwanie nad całokształtem pomyślności publicznej. Działo się tak przede wszystkim dlatego, że zasada specjalizacji, bezkrytycznie przeceniana, sprzyjała załatwianiu poszczególnych spraw życiowych odrębnie, najczęściej bez zdawania sobie sprawy z całości. Wydawało się przy tym - jak życie świadczy - niesłusznie, że ogrom potrzeb opiekuńczych nakazuje zajmowanie się tylko wyjątkami. Wpłynęło to np. na skrzywienie rozwoju ośrodków zdrowia, pomyślanych jako urządzenia profilaktyczne, prowadzące szeroką propagandę higieny, werbujące członków. Zostawszy działem zdrowia instytucji opiekuńczej ośrodek objął opiekę nad nieubezpieczonymi, przede wszystkim nad wykolejonymi przez bezrobocie. Niektóre tylko czynności z zakresu zapobiegania chorobom zakaźnym (związane po części z urzędami sanitarnymi) zachowały charakter powszechny.

Jak dalece potrzebne były w życiu instytucje obejmujące całokształt pomyślności, świadczy niejeden fakt z dziejów warszawskich ośrodków zdrowia i opieki, zwłaszcza od chwili, gdy poczekalnie ich zapełnił element ludzki, pełnowartościowy fizycznie i zawodowo, dotychczas zaradny, gospodarczo samowystarczalny, który wykoleiło bezrobocie. Zjawienie się tego elementu, posiadającego przyzwyczajenia i ambicje uznawane za normalne w pełnowartościowym kręgu życia, zmieniło w znacznym stopniu charakter ośrodków, skłoniło do podniesienia świadczeń, do objęcia nimi kształcenia dzieci, utrzymania kultury mieszkaniowej itp. Zmiany nie były jednak dostatecznie uświadomione, nie znalazły dość wyraźnego uwzględnienia w organizacji i przepisach, wynikło stąd, zwłaszcza w okresie bezrobocia, wiele szkód dla włączonych wbrew ich dążeniom w środowiska wykolejeńców. Najubożsi, dawni klienci ośrodka, zyskali jednak niewątpliwie wskutek tego, że wówczas, gdy na dno życia społecznego opadli ludzie mający niegdyś prawo do instytucji pomyślności, zrozumiano, jak straszne było życie na tym dnie ${ }^{47}$.

Kontynuując wypowiedź o skutecznej i całościowej działalności, cytowana autorka akcentowała walory kompleksowego przygotowania działaczy do planowanej służby:

\footnotetext{
${ }^{46}$ H. Radlińska, Listy o nauczaniu i pracy badawczej, s. 445, 474-475.

${ }^{47}$ H. Radlińska, Pedagogika społeczna, s. 341-342.
} 
Konieczne jest szerokie przygotowanie działaczy pełnych inicjatywy, sprawnych i odpowiedzialnych. Przeszkolenie sanitarne i gospodarcze, rozpoczęte już dawniej, nie wystarczy. Prace wymienione wymagają wyrobienia społecznego: organizatorskiego i wychowawczego, które wzmoże zapał i dobrą wolę przez umiejętność zrozumienia człowieka i zobaczenia zadań będących częścią ogólnego planu.

Wychowanie instruktorów powinno wykształcić wyobraźnię społeczną, która pozwoli w lot zorientować się w różnorodnych stosunkach, dostosowywać do nich zamierzenia ogólne, odnajdywać siły i środki.

Działalność doraźna liczyć się powinna z przyszłym układem stosunków, spożytkowywać okres przejściowy dla zapoczątkowania nowego życia ${ }^{48}$.

Podkreślając holistyczną perspektywę ujmowania zagadnień związanych z teorią i praktyką, kształceniem i badaniem w polu pedagogiki społecznej, Helena Radlińska zakreślała także liczne obszary aktywności pedagoga społecznego. Przyjmując kryterium ról podejmowanych w przestrzeni służby społeczno-pedagogicznej, wskazać tu można przede wszystkim funkcje związane z wychowaniem. Pedagog społeczny postrzegany jako wychowawca społeczny zdaje się wiodąca postacią koncepcji Heleny Radlińskiej. Wychowawcza rola jest bowiem fundamentem konstytuującym wszelkie pozostałe pola aktywności wpisujące się w przestrzeń służby pedagoga społecznego. W szczególności zaliczyć tu można takie jak: służba oświatowa (andragog, bibliotekarz), służba społeczna (pracownik społeczny, inżynier społeczny, asystent rodziny i młodzieży, pomocnik, opiekun, ratownik, profilaktyk, resocjalizator itp. $)^{49}$. Każda z funkcji zawodowych wiąże się również z aktywnością badawczą, która stanowi punkt bazowy dla diagnozy stanu faktycznego i określenia celów, zadań oraz harmonogramu planowanych działań.

Charakteryzując pedagoga społecznego pełniącego role wychowawcze, Helena Radlińska pisała, że:

Wychowanie różnych grup wieku współżyjących w pokoleniu historycznem splata się ze sobą.

Sprawą najważniejszą staje się rozumienie innych, poszanowanie odrębności, uczenie się oceny miary, jaką inni przykładają do spraw dla nas dalekich lub niezrozumiałych, czy przeciwnie - jedynie bliskich. Praca wychowawcza wśród dorosłych, ułatwiając świadomy udział starszego pokolenia w budowaniu przyszłości, wzmacnia więź rodzinną, obniża bowiem (nieunikniony

48 Tamże, s. 342. O kształceniu pracowników oświatowych i społecznych zob. także: tamże, s. 248 i n., s. 383 i n.

${ }^{49}$ Szerzej o zakresach aktywności zawodowej pedagoga społecznego pełniącego różnorodne role zob.: tamże, s. 26-27, 52-62, 275-277, 333-341, 354 i n.; H. Radlińska, Oświata dorostych. Zagadnienia, dzieje, formy, pracownicy, organizacja, Ludowy Instytut Oświaty i Kultury, Warszawa 1947; taż, Zagadnienia bibliotekarstwa i czytelnictwa; taż, Szkoły pracy spolecznej w Polsce, Komitet Polski Międzynarodowej Konferencji Służby Społecznej, MPiOS, Warszawa 1928; H. Orsza, T. Bobrowski, Z. Daszyńska-Golińska i in. (red.), Praca oświatowa. Jej zadania, metody, organizacja, Uniwersytet Ludowy im. Adam Mickiewicza, nakładem Michała Arcta w Warszawie, Kraków 1913; H. Radlińska, Stużba społeczna pielęniarki. Pogadanki o podstawach psychologicznych i pedagogicznych pracy pieleggniarek, Zarząd Główny PCK, Warszawa 1935 i inne. 
w pewnym stopniu) antagonizm generacyj. Wytwarzają się metody ratowania współżycia rodzinnego przed licznemi niebezpieczeństwami, które mu grożą rozbiciem, i równocześnie - zapobiegania złym skutkom ciasnoty rodzinnego egoizmu ${ }^{50}$.

W odniesieniu do pracy z młodzieżą cytowana autorka podkreślała wspomagającą rolę pedagoga społecznego podejmującego role wychowawcze:

Wychowawcy nie mogą wykonywać pracy za młodzież: dawanie nie zastępuje szukania; mogą jednak dopomóc i dla postawionego problematu ważna jest sprawa rodzaju tej pomocy.

Kształtowanie młodzieży w sposób krótkowzroczny nigdy w dziejach nie dawało zamierzonego wyniku. Pozwalało osiagać częściowe powodzenie w tych tylko przypadkach, gdy starsi, owi kształtujący, sami zdobywali codziennym wysiłkiem wyraz dla swych ideałów, gdy czerpali z głębokiego i czystego źródła. Młodzi uczestnicy tego samego pokolenia historycznego szli wówczas za nimi, wnosząc świeże siły do realizacji wspólnych zadań. Gdy jednak rządzący chcieli przekazywać gotowe formy, nie osiagali zamierzeń: młodzież szła swoją drogą i odwracała się nawet od istotnych wartości, których część narzucano ${ }^{51}$.

Przybliżając zakres badań i działalności praktycznej pedagoga społecznego, pisała Helena Radlińska o aktywizowaniu sił, które prowadzą do zmiany i rozwoju społecznego osób, rodzin, grup społecznych i całych społeczności żyjących w określonych przestrzeniach służby:

Celowe wprowadzanie czynników, które, nastawiając wolę ludzką, mają podtrzymywać lub zmieniać istniejące struktury rola wszechstronnie rozpatrywanej twórczości indywidualnej i zbiorowej, zwróconej ku budowaniu jutra wedle wzoru, zależnego od sił działających i narastających; możliwości i zakresu wpływu różnorodnych czynników przebudowy - oto własne pole badań i eksperymentów pedagogiki społecznej ${ }^{52}$.

Uzupełnić warto z perspektywy późniejszych doświadczeń II wojny światowej i towarzyszących temu eksperymentów prowadzonych przez faszystowskich pseudonaukowców w obozach zagłady, że Helena Radlińska w powojennym okresie nie sięgała swobodnie do tego rodzaju badań. W publikacjach poświęconych zagadnieniom metodologicznym odwoływała się do kategorii doświadczeń, wskazując jednocześnie, że nie jest to zbyt często wykorzystywana metoda poznania społeczno-pedagogicznego. Powodem były trudności w naturalnym odniesieniu do grup kontrolnych, co można odczytywać jako troskę o podmiotowość i humanistyczny wymiar poznania pedagoga społecznego postulowany przez cytowaną autorkę ${ }^{53}$.

Kontynuując zaś dalszy wywód metodyczny, stanowiący jednocześnie zarys pola praktyki specyficzny dla pedagoga społecznego, kreśliła Helena Radlińska

\footnotetext{
${ }^{50}$ H. Radlińska, Stosunek wychowawcy do środowiska społecznego, s. 59-60.

${ }^{51}$ H. Radlińska, Pedagogika społeczna, s. 26-27.

${ }^{52}$ H. Radlińska, Stosunek wychowawcy do środowiska społecznego, s. 16.

${ }^{53}$ Por. H. Radlińska, Egzamin z pedagogiki społecznej, s. 374.
} 
porównawczą analizę dyscypliny, zestawiając pedagogikę społeczną z polityką społeczna, do której była w okresie międzywojennym przyrównywana ${ }^{54}$ :

Pedagogika społeczna - w odróżnieniu od polityki społecznej, kładzie szczególny nacisk na stosunek wzajemny czynników biologicznych społecznych.

Podział istniejących dóbr interesuje jąjako zapewnienie warunków rozwoju i podstawa dalszej twórczości jednostki i gromady. Działalność grup społecznych jest dla niej polem obserwowania wpływów, nastawiających wolę, kształtujących postępowanie człowieka. Właściwy zakres wychowania upatruje przytem w oddziaływaniach, które wzmagają siły jednostek, pielęgnują zadatki uzdolnień, skierowują pęd twórczy. [...]

W teraźniejszości, splatającej wczoraj i jutro, ścierają się różne prądy, powstają różne wzory. Zadaniem wychowania jest ułatwiać orjentowanie się w ich chaosie. Wbrew tradycyjnym określeniom nietyle „przystosowuje” ono nowe pokolenia do istniejących warunków bytu, co dopomaga do odnalezienia w dniu dzisiejszym wartości, które stanowią najmocniejsze oparcie dla nowych poczynań.

Nietylko w teoryjach pedagogicznych, lecz i w opinji publicznej, toruje sobie zrozumienie pogląd, że wychowanie jest w pewnym sensie służbą nieznanemu (tak samo zresztą jak wszelka twórczość ludzka). Wychowawcy nie mogą sobie wyobrazić układu życia, do którego przygotowuja, ani narzędzi pracy, które weźmie do ręki nowe pokolenie. Staje się to jasne wobec szybkiego tempa, wszechstronności rozległości przemian, zachodzących współcześnie na wszystkich polach. Urzeczywistnienie ideałów odbywa się w kształtach nieprzewidzianych. Dlatego t. zw. ,nowe wychowanie" podkreśla konieczność przygotowania do swobodnej twórczości indywidualnej i zespołowej, wpatrując się w możliwości, które tkwią w dziecku, nie we wzorzec życia, obmyślony dla dziecka ${ }^{55}$.

Pisany w trzeciej dekadzie XX w. tekst zdaje się wciąż aktualny, gdy weźmie się pod uwagę jego przesłanie i uniwersalny wymiar. Dostrzegane przed niemal stu laty przyspieszenie w rozwoju cywilizacyjnym jest współcześnie podkreślane jako szczególne i wyjątkowe w skali globalnej oraz historycznej. Uważna lektura przywołanego fragmentu, a szczególnie całości cytowanego dzieła, z pewnością może inspirować do stawiania pytań o ową wyjątkowość, niepowtarzalność czy „zawrotność” tempa akceleracji powodowanej osiagnięciami technologii XXI w. Nie trudno przy tym rozpoznać ogólne tendencje i zbieżność dostrzeganych w danej współczesności kontrastów względem określonej historycznie przeszłości. W szczególności można stwierdzić, że w każdej epoce i pokoleniu warto spoglądać z ostrożnością na przebiegi procesów zmian. Użyteczna w waloryzacji określonych rezultatów dokonujących się przeobrażeń jest znajomość historii, a także zdolność analizy z perspektywy makro. Przyjąć można, że narzędzia służące analizie są swoistym zabezpieczeniem dla pedagoga społecznego przed przedwczesnym nadawaniem znaczeń i wartości dostrzeganym zjawiskom,

${ }^{54}$ Jednym z wiodących oponentów wyodrębniania w nauce „,nowej dyscypliny” - pedagogiki społecznej, był Konstanty Krzeczkowiski. Czynił on zarzuty zarówno wobec Heleny Radlińskiej, jak i budowanej przez nią dyscypliny dotyczące podobieństwa pola przedmiotowego zagospodarowanego przez politykę społeczną. Zob. szerzej: H. Radlińska, Listy o nauczaniu i pracy badawczej, s. $427 \mathrm{i}$.

${ }^{55}$ H. Radlińska, Stosunek wychowawcy do środowiska społecznego, s. 16-20. 
zdarzeniom czy procesom. W odniesieniu do społecznego wymiaru zmian dokonujących się na przestrzeni wieków warto pamiętać, że postęp technologiczny, który bez wątpienia warunkuje jakość ludzkiej egzystencji, nie może być jedynym kryterium oceny zdarzeń towarzyszącym procesom rozwoju ludzkości. Przewartościowania w sferze ekonomicznej czy technicznej mogą prowadzić do dehumanizacji i marginalizacji człowieka w polu widzenia określonych dyscyplin nauki i profesji działalności praktycznej.

\section{Zaproszenie do dyskursu}

Przyjęte na początku wypowiedzi założenia dyscyplinarne, teoretyczne i metodologiczne, jakie towarzyszyły kreśleniu niniejszego obraz pedagoga społecznego w ujęciu Heleny Radlińskiej, stanowiły punkt odniesienia w toku realizacji zamierzonego celu. Rekonstrukcja koncepcji pedagoga społecznego była możliwa przy zastosowaniu różnorodnych kryteriów i narzędzi analizy. Wybrane w tym opracowaniu nie są jedynymi i każdy z odbiorców może stosować indywidualne podejście do wyznaczonej tu problematyki. Kluczowe zdaje się jednak, aby oceniający wybrany tu sposób budowy obrazu pedagoga społecznego nie poprzestawali na krytykanckim podejściu do udostępnionej propozycji, ale samodzielnie zaproponowali autorski projekt, który wzbogaci dyskurs o polskim pedagogu społecznym według koncepcji Heleny Radlińskiej. Dyskurs ten jest o tyle ważny, że minęło już ponad 100 lat od inicjacji dyscyplinarnej polskiej pedagogiki społecznej ${ }^{56}$. Warto zatem wracać do idei upowszechnienia kształcenia społeczno-pedagogicznego oraz zawodowego umocowania absolwentów tego kierunku studiów, który w wymiarze formalnym funkcjonował w czasie akademickiej aktywności Heleny Radlińskiej na Uniwersytecie Łódzkim ${ }^{57}$.

Spodziewaną wątpliwość może budzić liczne cytowanie fragmentów oryginalnych dzieł autorki. Wyjaśnienie tej kwestii znajduje się w początkowym fragmencie rozważań, ale warto i w tym miejscu podkreślić, że jest to zabieg celowy, zamierzony i powodowany względami tak merytorycznymi, jak i technicznymi. Znajomość nazwiska przywoływanej tu autorki jest powszechna i co do tego nie ma żadnych wątpliwości. Jednakże dostęp do jej prac oraz ich znajomość

${ }^{56}$ Za dyscyplinarny początek przyjmuje się wystąpienie Heleny Radlińskiej w Krakowskim Kole Towarzystwa Nauczycieli Szkół Średnich i Wyższych, które odbyło się 25 kwietnia 1908 r. Autorka zaprezentowała referat pt. Z zagadnień pedagogiki społecznej, w którym zarysowała poglądy na szkołę, autonomię nauczycieli oraz konieczność rozszerzania oświaty powszechnej celem wzrostu poziomu wykształcenia w narodzie. Zob. H. Radlińska, Z zagadnień pedagogiki społecznej, „Muzeum” 1908, t. 1, s. 52-63. Zob. także: I. Lepalczyk, Helena Radlińska, życie i twórczość, s. 40.

${ }^{57}$ Zob. H. Radlińska, Listy o nauczaniu i pracy badawczej, s. 462 i n.; I. Lepalczyk, Helena Radlińska, życie i twórczość, s. 135 i n. 
w środowisku zachęca do przybliżania tekstów źródłowych. W Katedrze Pedagogiki Społecznej Uniwersytetu Łódzkiego powstał projekt badawczy, którego celem było włączenie się w „Narodowy Program Rozwoju Humanistyki” (rok zgłoszenia - 2013). Zgłoszenie merytorycznego projektu ze względów formalnych nie przyniosło powodzenia. Nie był poddany procedurze recenzji jako niezgodny z programem. Można domniemywać, że zadecydowały względy administracyjne, z których wynika, iż pedagogika jest dyscypliną naukową wpisaną do grupy nauk społecznych, nie zaś humanistycznych. W trakcie przygotowania tego tekstu procedowany jest projekt zgłoszony do programu „Pomniki polskiej myśli filozoficznej, teologicznej i społecznej XX i XXI wieku" (rok zgłoszenia $2016)^{58}$. Intencją obu projektów jest odnalezienie, uporządkowanie i upowszechnienie dzieł rozproszonych (oraz częściowo zebranych i wydanych w latach 1961-1979) Heleny Radlińskiej. Towarzyszy temu zamiar wznowienia wydań, co umożliwi oddanie na platformie cyfrowej tekstów autorskich bez ingerencji cenzury politycznej, której poddawane były wszelkie publikacje tzw. pierwszego obiegu w okresie PRL. Obecnie projekt pomnika społecznej myśli Heleny Radlińskiej jest w fazie rozpatrywania, co skłania do wiernego odtworzenia poglądów w wybranym tu zakresie. Nie jest to pełne obrazowanie wyczerpujące poglądy Heleny Radlińskiej na zagadnienia związane z pedagogiem społecznym i tożsamą mu dyscypliną akademicką. Jednakże przyjąłem założenie, że wiernie odtworzone fragmenty wypowiedzi autorki będą inspirowały do dalszych, samodzielnych poszukiwań czytelników, którym bliskie są sprawy związane z polską pedagogiką społeczną i jej dyscyplinarnym reprezentantem - pedagogiem społecznym. Ostateczna ocena konstrukcji tekstu opartego na licznych i bogatych w treści cytatach pozostaje bez wątpienia po stronie odbiorcy, a uwagi krytyczne (z pominięciem krytykanctwa) oraz autorskie propozycje w przedmiotowym zakresie będą z pewnością komponentem wzbogacającym dyskurs o źródłach i tożsamości polskiego pedagoga społecznego.

\section{Bibliografia}

Kuhn T. S., Struktura rewolucji naukowych, Wydawnictwo Aletheia, Warszawa 2009.

Lepalczyk I., Helena Radlińska: życie i twórczość, Wydawnictwo Adam Marszałek, Toruń 2001.

Lepalczyk I., Wasilewska B. (red.), Helena Radlińska. Człowiek $i$ wychowawca, TWWP, Warszawa 1994-1995.

Lepalczyk I., Wasilewska B. (red.), Helena Radlińska - portret pedagoga (rozprawy, wspomnienia, materiały), Wydawnictwo Uniwersytetu Łódzkiego, Łódź 1994.

${ }^{58}$ Informacje o statusie obu wymienionych projektów odczytano ze strony osf.opi - generatora wniosków projektowych - dostęp przez zakładkę kierownika obu projektów (Arkadiusza Żukiewicza). 
Marynowicz-Hetka E., Theiss W. (red.), Profesor Helena Radlińska. W sto dwudziesta piqta rocznicę urodzin i pięćdziesiata rocznicę śmierci, ŁTN, Łódź 2004.

Orsza H., Bobrowski T., Daszyńska-Golińska Z. i in. (red.), Praca oświatowa. Jej zadania, metody, organizacja, Uniwersytet Ludowy im. Adam Mickiewicza, nakładem Michała Arcta w Warszawie, Kraków 1913.

Palka S., Pedagogika teoretycznie i praktycznie zorientowana a badania historii wychowania i myśli pedagogicznej, [w:] T. Jałmużna, I. Michalska, G. Michalski (red.), Konteksty i metody w badaniach historyczno-pedagogicznych, Oficyna Wydawnicza Impuls, Kraków 2004.

Radlińska H., Egzamin z pedagogiki społecznej, [w:] taż, Pedagogika społeczna, Ossolineum, Wrocław 1951 (1961).

Radlińska H., Listy o nauczaniu i pracy badawczej, [w:] taż, Z dziejów pracy społecznej i oświatowej, Ossolineum, Wrocław 1953-1954 (1964).

Radlińska H., Oświata dorostych. Zagadnienia, dzieje, formy, pracownicy, organizacja, Ludowy Instytut Oświaty i Kultury, Warszawa 1947.

Radlińska H., Oświata i kultura wsi polskiej. Wybór pism, Ludowa Spółdzielnia Wydawnicza, Warszawa 1979.

Radlińska H., Pedagogika społeczna, Ossolineum, Wrocław 1961.

Radlińska H., Planowanie pracy wychowawczej na tle środowiska, „Ruch Pedagogiczny” 1933/1934, nr 5.

Radlińska H., Program i metoda badania dziejów pracy oświatowej, [w:] taż, Z dziejów pracy spoŁecznej i oświatowej, Ossolineum, Wrocław 1933 (1964).

Radlińska H., Program pracy oświatowej, „Kultura Polski” 1917, z. 7-9.

Radlińska H., Stużba społeczna pielęniarki. Pogadanki o podstawach psychologicznych i pedagogicznych pracy pielęgniarek, Zarząd Główny PCK, Warszawa 1935.

Radlińska H., Spojrzenie na rzeczywistość, „Oświata i Kultura” 1946, nr 5-6.

Radlińska H., Stosunek wychowawcy do środowiska społecznego. Szkice z pedagogiki społecznej, Nasza Księgarnia, ZNP, Warszawa 1935.

Radlińska H., Szkoły pracy społecznej w Polsce, Komitet Polski Międzynarodowej Konferencji Służby Społecznej, MPiOS, Warszawa 1928.

Radlińska H., Technika pierwszej pracy naukowej, Łódź 1950; skrypt wydany przez Koło pedagogów społecznych Uniwersytetu Łódzkiego.

Radlińska H., W sprawie badań historyczno-pedagogicznych, „Przegląd Historyczny” 1922, z. 2.

Radlińska H., Z dziejów pracy społecznej i oświatowej, Ossolineum, Wrocław 1964.

Radlińska H., Z zagadnień pedagogiki spotecznej, „Muzeum” 1908, t. 1.

Radlińska H., Zadania pracy kulturalnej, „Kultura Polski” 1917, z. 1.

Radlińska H., Zagadnienia bibliotekarstwa i czytelnictwa, Ossolineum, Wrocław 1961.

Radlińska H., Zagadnienia opieki społecznej. Ze skrzyżowań teorii i praktyki, „Praca i Opieka Społeczna" 1947, nr 4.

Radlińska H., Zasięg wychowania, „Ruch Pedagogiczny” 1946, nr 1.

Theiss W., Badania historyczno-oświatowe w pedagogice społecznej, „Studia Pedagogiczne” 1982, z. 9, Zeszyty Naukowe Wyższej Szkoły Pedagogicznej w Bydgoszczy.

Theiss W., Radlińska, Wiedza Powszechna, Żak, Warszawa 1984, 1997.

Theiss W. (red.), Listy o pedagogice społecznej: Helena Radlińska, Aleksander Kamiński, Adam O. Uziembło, Żak, Warszawa 1997.

Topolski J., Metodologia historii, PWN, Warszawa 1984. 